\title{
Physical Transport Processes that Affect the Distribution of Oil in the Gulf of Mexico OBSERVATIONS AND MODELING
}

By Michel Boufadel, Annalisa Bracco, Eric P. Chassignet, Shuyi S. Chen, Eric D'Asaro, William K. Dewar, Oscar Garcia-Pineda, Dubravko Justić, Joseph Katz, Vassiliki H. Kourafalou, lan R. MacDonald, Tamay M. Özgökmen, Claire B. Paris-Limouzy, Scott S. Socolofsky, David Halpern, and John G. Shepherd

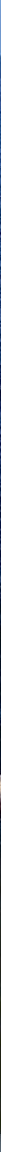

View from R/V Walton Smith where Gulf of Mexico and Mississippi River waters meet. Photo credit: Tamay Özgökmen 
ABSTRACT. Physical transport processes such as the circulation and mixing of waters largely determine the spatial distribution of materials in the ocean. They also establish the physical environment within which biogeochemical and other processes transform materials, including naturally occurring nutrients and human-made contaminants that may sustain or harm the region's living resources. Thus, understanding and modeling the transport and distribution of materials provides a crucial substrate for determining the effects of biological, geological, and chemical processes. The wide range of scales in which these physical processes operate includes microscale droplets and bubbles; small-scale turbulence in buoyant plumes and the near-surface "mixed" layer; submesoscale fronts, convergent and divergent flows, and small eddies; larger mesoscale quasigeostrophic eddies; and the overall large-scale circulation of the Gulf of Mexico and its interaction with the Atlantic Ocean and the Caribbean Sea; along with air-sea interaction on longer timescales. The circulation and mixing processes that operate near the Gulf of Mexico coasts, where most human activities occur, are strongly affected by wind- and river-induced currents and are further modified by the area's complex topography. Gulf of Mexico physical processes are also characterized by strong linkages between coastal/shelf and deeper offshore waters that determine connectivity to the basin's interior. This physical connectivity influences the transport of materials among different coastal areas within the Gulf of Mexico and can extend to adjacent basins. Major advances enabled by the Gulf of Mexico Research Initiative in the observation, understanding, and modeling of all of these aspects of the Gulf's physical environment are summarized in this article, and key priorities for future work are also identified.

\section{THE VIEW FROM ABOVE:} OBSERVATIONS OF SURFACE OIL

Important advances have been made in ocean observing through both in situ and remote-sensing technologies that include drifters, satellite and aircraft sensors, and high-frequency ocean radar (HFR) systems, tools that are especially useful for determining transport at and immediately below the ocean surface (Morey et al., 2018; Rodríguez et al., 2018). Data collected using these methods show that the velocities measured right at the ocean surface, as opposed to many centimeters or meters below it, are much greater than previously thought, and these differences need to be accurately represented in models (Le Hénaff et al., 2012; Wenegrat et al., 2014). From April 22 to August 2, 2010, every available satellite was tasked with observing the northeastern Gulf of Mexico at every possible opportunity. Their collective mission was to detect floating oil that reached the ocean surface from wreckage of the Deepwater Horizon (DWH) rig and the blowout of the exploration well in the Macondo MC252 lease block. The effort yielded an unprecedented data set comprising over 200 opti- range of 2-10 $\mathrm{m} \mathrm{s}^{-1}$ (Daneshgar Asl et al., 2017). Unlike optical sensors, satellites with SAR detectors function irrespective of cloud cover or time of day (Leifer et al., 2012). The SAR scenes used in the study originated from Radarsat-1, Radarsat-2, TerraSAR-X, CosmoSKY-MED 1-2-3-4, ENVISAT, ALOS-1, and ERS-2. The resolution of this large SAR data set ranged from $10 \mathrm{~m}$ to $25 \mathrm{~m}$ per pixel over $25 \mathrm{~km}$ to $450 \mathrm{~km}$ swaths. The Gulf of Mexico region where oil was detected in each SAR scene was gridded at a $5 \mathrm{~km}$ scale so that results could be summarized across large ocean areas in a time lapse throughout the duration of the spill (Holmes et al., 2017).

The NRDA team developed two innovative approaches to further analyze the data. While each scene generally covered hundreds of square kilometers, the total extent of the floating oil was often much greater in area; thus, each image captured only samples of the larger phenomenon. To obtain an interpolated and gridded time series showing the areal extent of the entire oil slick at $12 \mathrm{~h}$ intervals, MacDonald et al. (2015) authors Solow and Beet developed a statistical method in which the oiled areas detected in each SAR scene were treated as unbiased samples of the total oil layer. Images of floating oil slicks were highly patchy and heterogeneous in apparent thickness. To estimate the volumes of oil represented by different portions of the oil layer, Garcia-Pineda et al., 2013a,b) developed image-processing methods that analyzed the signal strength of SAR pixels to distinguish between "thin" or "thick" layers (nominally $1 \mu \mathrm{m}$ and $72 \mu \mathrm{m}$, respectively).

Results could be interpreted in relation to environmental factors (e.g., wind speed), the rate of discharge from the well, and in the context of response operations such as surface oil burning and application of dispersant by aerial and submarine methods. Figure 1 shows the average extent of surface oil in units of $\mathrm{m}^{3} \mathrm{~km}^{-2}$. An animation of the $12 \mathrm{~h}$ estimates, augmented with data wind speed can be viewed at https://www.youtube.com/ watch $\mathrm{v}=\mathrm{v} 1 \mathrm{kkniG} 7 \mathrm{atA} \& \mathrm{t}=4 \mathrm{~s}$, and origi- 


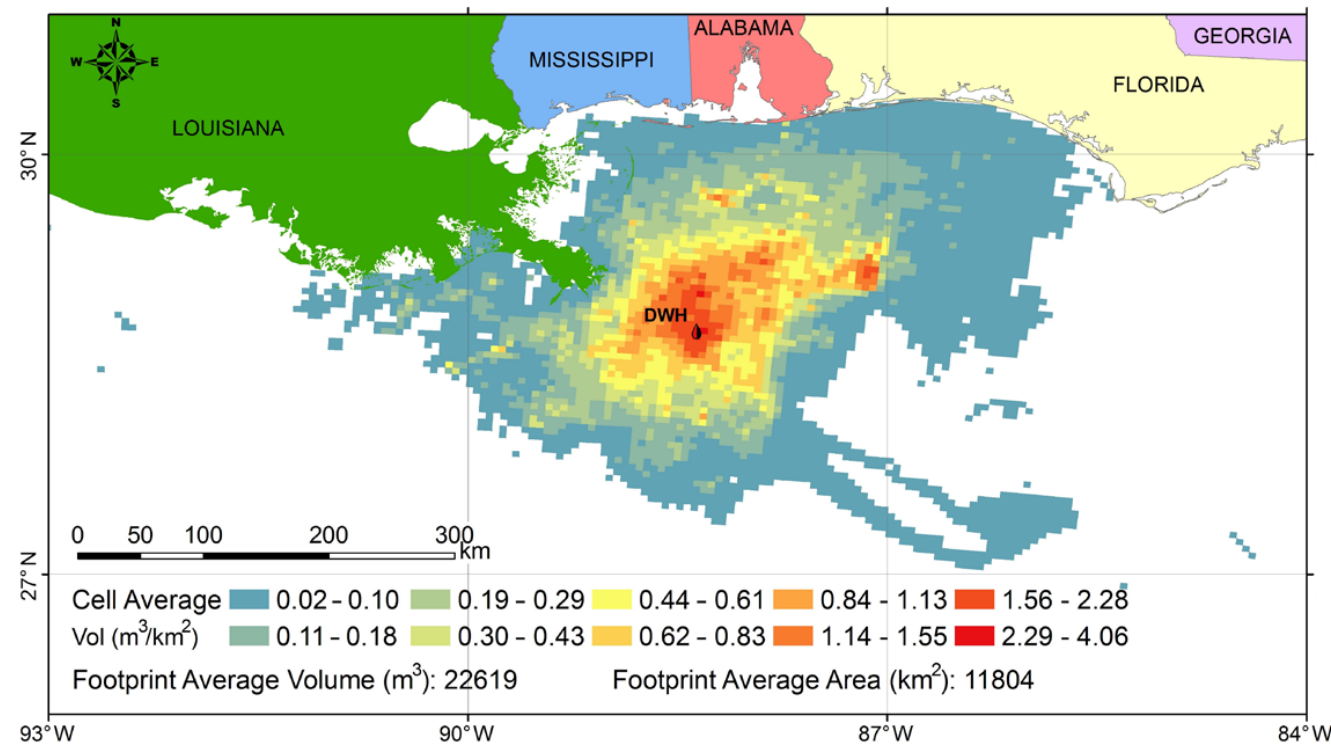

FIGURE 1. Distribution and average volume of surface oil $\left(\mathrm{m}^{3} \mathrm{~km}^{-2}\right)$ from the Deepwater Horizon (DWH) discharge, gridded at $5 \times 5 \mathrm{~km}$ scale across a cumulative footprint of $149,000 \mathrm{~km}^{2}$, from April 24, 2010, to August 3, 2010. From Figure 3 in MacDonald et al. (2015)

nal data can be retrieved from the GRIIDC database (MacDonald, 2019).

The unprecedented remote-sensing data set has been used not only to better understand the extent and impact of the DWH spill but also to develop better methods and technologies for detecting oil spills. For example, during the spill in 2010, it could take several days to provide spill responders with a processed satellite image; this process has now been narrowed to a matter of minutes. In parallel, methods for extracting more detailed characterizations of the floating layers of oil from SAR satellite images (emulsification, thicknesses, and/or discerning false positives) have also been substantially improved.

The findings from this study have been used in a number of subsequent investigations, including how floating oil impacts benthic deposition by marine snow (Daly et al., 2016); the responses of the microbial community to the spill (Joye et al., 2016b); the spill's impacts on seabirds (R.M. Huang et al., 2017), fishes (Price and Mager, 2020), and cephalopods (Romero et al., 2020); and the extent of fishery closures (Berenshtein et al., 2020). One novel result concerned the possible impact of dispersant applications. There were two roughly equivalent periods of the oil spill during which winds were low and oil slicks could spread with reduced mixing from wave action: peaks in the total area and the volume of the floating oil layer were observed on May 23 and June 18, 2010. Between these peaks, the total volume of floating oil decreased by $21 \%$, while the ocean area over which the floating oil spread increased by $49 \%$ (Figure 2). On approximately June 3, responders began application of up to $50,000 \mathrm{~L} \mathrm{~d}^{-1}$ of Corexit dispersant directly into the discharging oil plume at depth (Lehr et al., 2010). Thus, the satellite data suggest that the submarine dispersant application may have achieved a reduction in the total volume of surface oil, but with the side effect of increasing the area over which the residual volume was dispersed. In addition, after June 1-3, the damaged end of the riser of the well was cut off, and a new cap/collection system was installed that siphoned off $\sim 15,000$ barrels per day, or $20 \%-25 \%$ of the oil released (Griffiths, 2012), also contributing to the measured decrease in floating oil. It is hoped that this experiment in satellite remote sensing of an oil spill will not be repeated, but the data obtained were and will remain an important resource for understanding the dynamics of floating oil in the marine environment.

\section{MICROSCALE PHYSICAL (AND BIOPHYSICAL) PROCESSES}

GoMRI research included a series of studies focused on measuring and modeling the very small-scale physical and chemical processes that affect the interactions of oil with the marine environment. These investigations include: (a) physical breakup of oil slicks by waves and the associated effects of dispersants; (b) measuring and modeling the breakup and droplet generation in submerged oil jets and plumes; (c) applications of Large Eddy Simulations (LES) to simulate coherent oil plumes in the marine environment; (d) characterization of interfacial phenomena involving oil, dispersants, and bacteria, and mass transport at oil-water interfaces; and (e) phenomena involving the aerosolization of oil. All of these aspects are discussed below.

\section{Breakup of Oil Slicks}

Wave tank measurements (C. Li et al., 2017; Afshar-Mohajer et al., 2018) provide a comprehensive database on the spatial and temporal size distribution of subsurface droplets as a function of wave energy, dispersant concentration, oil viscosity, depth, and time after wave breaking. The measured time evolution of turbulence in the tank has been used for correlating the evolution of droplet size distribution to their subsurface transport. As expected, for fresh crude oil without dispersant, after wave breaking, the measured rate of droplet disappearance from the water column increases with buoyancy and with droplet size. This can be predicted based on a solution to an 


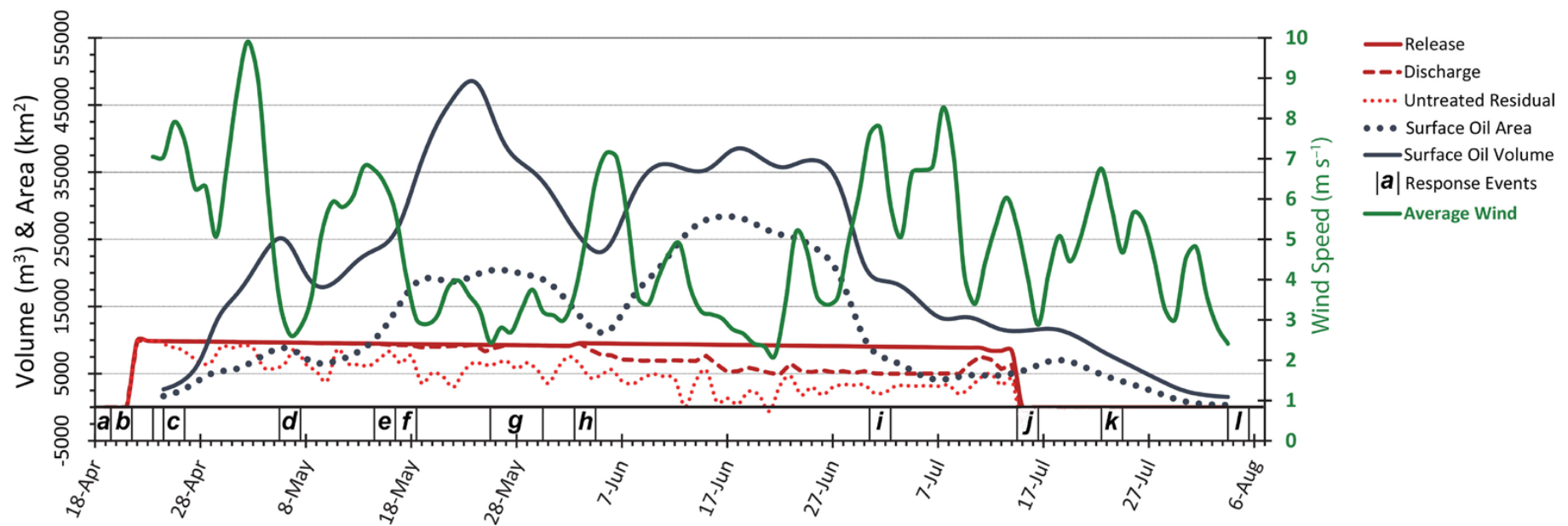

FIGURE 2. Time series of DWH discharge during 2010, plotted with surface oil and average wind speeds. Release magnitudes show best daily estimates of oil escaping from the damaged well. Discharge subtracts the oil recovered from the gross release, while treatment further subtracts that burned and dispersed by aerial and subsea applications of Corexit at maximum efficacy. Response events that potentially affected the spread of surface oil are: (a) Macondo well blowout occurs, (b) DWH drillship sinks and release begins, (c) aerial dispersant application begins, (d) containment dome attempt fails and burning of surface oil begins, (e) subsea dispersant campaign begins (May 5), (f) flaring of recovered oil begins, (g) top-kill attempt made, (h) riser is cut from blowout preventer and direct oil collection subsea and injection of subsea dispersant begins, (i) Hurricane Alex makes landfall, (j) capping stack closure stops release, (k) Tropical Storm Bonnie makes landfall, and (I) well is killed by static backfill. From Figure 7 in MacDonald et al. (2015)

unsteady advection-diffusion (turbulent) equation, and the characteristic droplet sizes are consistent with models involving turbulent Weber numbers. ${ }^{1}$ The results have subsequently been used for validating predictions of wave breaking and for modeling oil transport after spills, and also to support parallel numerical simulations and characterization of chaotic phenomena in wave breaking (Wei et al., 2018). Application of dispersant (Corexit 9500) causes major changes in droplet size distributions, reducing the concentration of millimeter-size droplets and increasing the concentrations of microdroplets. For a dispersant-to-oil ratio (DOR) of 1:25 in particular, the micron-scale droplets are generated by an interfacial phenomenon called tip streaming (Gopalan and Katz, 2010). This phenomenon involves generation of long oil strings that extend from separation points on the surface of the droplet. The Weber-number-based predictions of droplet sizes do not account for these interfacial phenomena, and hence they overpredict droplet sizes. A computational study aimed at elucidating the causes for tip streaming (Tseng and Prosperetti, 2015) shows that it is generated by an instability that occurs near spe- cial points on the interface. Wherever the flow at the interface is locally convergent, any small perturbation on the interface tends to grow because of the combination of compression and viscous shear stress. The effect of surface tension opposes this growth, but its influence is inhibited in the presence of surfactants, especially because the convergent flow also accumulates the surfactants in its vicinity.

\section{Droplets in Oil Jets and Plumes}

Considerable effort has been made to measure and model droplet size distributions in jets and plumes. Relying on classical turbulent models, Johansen et al. (2013) introduced a semi-empirical Weber-number-based model for the size of oil droplets in jets that has been subsequently updated using experimental data (Brandvik et al., 2013, 2014; Johansen et al., 2013, 2015). They also characterized depth effects (Brandvik et al., 2019), and introduced new methods for classifying oil droplets, particles, and bubbles based on their quasi-silhouette images (Davies et al., 2017). Corrections for large jets, which account for the maximum possible droplet size, are discussed by Z. Li et al. (2017a,b). These models also account for the effect of dispersant through reduction of the interfacial tension, but not for the interfacial processes, such as tip streaming, which is believed to be responsible for generating micron-size droplets Murphy et al., 2016; Zhao et al., 2017). Another approach, the VDROPJ model (Zhao et al., 2014a) uses the droplet population dynamical model VDROP (Zhao et al., 2014b) and applies it to control volumes in the near fields of the jet/ plume, thus allowing for changes in jet hydrodynamics to impact the size distribution. VDROP allows for breakup and coalescence of droplets, accounts for resistance to breakup by interfacial tension and viscosity, and includes modules that simulate tip streaming. While the microdroplets account for only a small percentage of the total oil volume, they are more likely to be entrained into the intrusion layers (D. Wang and Adams, 2016; Gros et al., 2017), whereas larger droplets (e.g., $>500 \mu \mathrm{m}$ ) tend to rise directly to the surface (Zhao et al., 2015).

Murphy et al. (2016) describe droplet sizes and spatial distributions and the flow mechanisms affecting them in the near field of oil jets in realistic cross-flow conditions. They show that the bottom

\footnotetext{
The Weber number describes the magnitude of the hydrodynamic forces that tend to disrupt droplets, relative to the surface tension that tends to stabilize them.
} 
part of the oil plume near field is dominated by entrainment of droplets into the counter-rotating horizontal vortex pair set up by the cross flow, while the upper part is determined by the buoyant rise of relatively large droplets. Because the plume structure is strongly influenced by the droplets' size distributions, subsequent studies have focused on the breakup of vertical oil jets into droplets. Observations involving refractive index matched jets (Xue and Katz, 2019) show that most of the oil droplets are actually compound droplets; they contain smaller water droplets, which sometimes contain even smaller oil droplets. The fraction of compound droplets increases with droplet size, exceeding $80 \%$ for $2 \mathrm{~mm}$ droplets. These compound droplets are generated when early phase shear layers roll up into vortices and entrain water filaments into the oil.

\section{Computational Modeling of Plume Behavior}

Studies of plume dispersion are challenging because of the multiscale flow physics involved, ranging from individual oil droplets to an entire plume and to mesoscale eddies in the upper ocean boundary layer. Applications of LES $^{2}$ methods to characterize such flows require parameterization of the subgrid-scale processes that are not resolved, including oil droplet and gas bubble formation, coalescence and breakup, gas dissolution, biodegradation, and hydrate formation. Several LESbased studies of oil and gas plumes have investigated the effect of droplet-scale physics on the plume-scale dispersion phenomena (Yang et al., 2016; B. Chen et al., 2016b, 2018). Among the many findings, they show that: (1) the significant reduction of oil droplet size caused by dispersant also enhances the vertical mixing of the oil in the ocean mixed layer, resulting in an Ekman-spiral-induced shift of the mean plume transport direction; (2) application of a recent droplet population balance model (Aiyer et al., 2019) in an LES framework (Chamecki et al., 2019) to simulate the effect of turbulence on oil droplet breakup reproduces the measured droplet size distributions (Murphy et al., 2016); (3) LES of subsurface plumes shows that gas dissolution from bubbles causes a considerable reduction in plume buoyancy and impacts the peeling/intrusion processes. A related theoretical study investigated the dissolution of multi-component oil drops in water, where the surface concentration of solutes depends on the drop composition and varies as the drop dissolves due to the different solubilities of individual components (Chu and Prosperetti, 2016). The analysis involves a first-principles demonstration of the necessary modeling strategy based on the fundamental law of equality of each component's chemical potentials in the drop and in the external solvent.

\section{Interactions Between Microbes, Particles, and Oil Droplets}

A series of experimental studies have focused on micrometer-scale interactions between microbes, particles, and oil droplets (Sheng et al., 2006; Molaei and Sheng, 2014; Jalali et al., 2018; White et al., 2019a). The degradation of 5-100 $\mu \mathrm{m}$ droplets through dissolution and biodegradation by bacterial isolates and natural microbial consortia, with and without dispersant, was measured using microfluidic flows over a surface textured with microdroplets (Jalali et al., 2018). For $100-1,000 \mu \mathrm{m}$ droplets, the experiments were performed in a unique ecology-ona-chip microcosm platform that allows examination of bacterial behavior and microbial community responses around a rising micro-oil droplet, along with measurements of associated flows and rheological mechanisms (White et al. 2019a,b). These studies demonstrate the formation of polymeric microbial aggregates as well as extra-cellular polymeric substance (EPS) streamers around rising oil droplets, both of which affect the droplets' hydrodynamic impacts-even a few isolated streamers can increase the drag on a drop by $80 \%$. Another study of bacterial interactions with alkaneaqueous interfaces (Vaccari et al., 2017) shows that these interactions depend strongly on the particular strain of bacteria. The bacteria can either continue to swim adjacent to the interface or become attached to it. If they become attached, they may form a thin solid elastic film (Vaccari et al., 2015). Some, but not all, of the observations suggest that the ability to form such elastic films relies on the ability of the bacteria to metabolize the oil phase (Niepa et al., 2017). Bacteria near interfaces display a range of behaviors that includes Brownian motion, swimming in circular trajectories, and directed swimming (Deng et al., 2020). These motions can also enhance the dispersion and transport of micron-scale droplets (Vaccari et al., 2018).

\section{Aerosolization of Oil}

Surface oil slicks can be aerosolized either by splashing during wave breaking or by bursting of entrained bubbles as they rise back to the surface. While the size distributions of marine aerosols have received considerable attention (Veron, 2015), very limited information exists about the process of aerosolization of oil slicks. However, a series of experiments investigated the effect of dispersants on the aerosolization of oil slicks by breaking waves (Afshar-Mohajer et al., 2018), and subsequently, the effect of bubble bursting at an oil-water interface (Sampath et al., 2019; Afshar-Mohajer et al., 2020).

In these wave tank experiments (Afshar-Mohajer et al., 2018), the aerosol size distributions were measured in sizes ranging from $10 \mathrm{~nm}$ to $20 \mu \mathrm{m}$ using a scanning mobility particle sizer (SMPS) for the 10-400 $\mathrm{nm}$ size range and an aerodynamic particle sizer (APS) for

\footnotetext{
${ }^{2}$ Large Eddy Simulation (LES) methods deliberately filter out very small-scale motions, which are the most computationally expensive to resolve, producing results that are smoothed somewhat in both space and time but that preserve the larger scale features.
} 
the 0.5-20 $\mu \mathrm{m}$ range. Digital holography (Katz and Sheng, 2010; C. Li et al., 2017) has also been used in parallel for detecting airborne droplets larger than $4 \mu \mathrm{m}$, showing good agreement with the APS data. The total particle-bound polycyclic aromatic hydrocarbons (pPAH) and the total volatile organic compounds (TVOCs) were measured concurrently. Data have been obtained for plunging breaking waves entraining slicks of crude oil (MC252 surrogate), crude oil-dispersant mixtures, and dispersant only. The results show that slicks of crude oil do not alter the concentration of nanodroplets. In contrast, the concentrations of nanoparticles originating from oil-dispersant mixture and dispersant alone are one to two orders of magnitude higher than those from crude oil alone across the entire nano-scale range, reaching 100 times for $20 \mathrm{~nm}$ particles. Conversely, adding dispersant has little effect on the concentration of micro-aerosols. The average concentrations of $\mathrm{pPAH}$ remain similar in range (150-270 $\mathrm{ng} \mathrm{m}^{-3}$ ). However, the VOC concentrations for crude oildispersant mixtures are two to three times lower than those of crude oil, in agreement with prior studies (Gros et al., 2017). An analysis of the health risk associated with the measured VOC and airborne particles is discussed in Afshar-Mohajer et al. (2019). Their results show that on the one hand, the lower VOC reduces the health risk. On the other hand, inhalation of the nanoparticles increases the total mass of deposited particles in the upper respiratory tract and tracheobronchial regions of the lungs, although the measured quantities were still well below the health risk threshold. However, the concentration of total suspended particles (micro plus nano scale) close to the source only just exceeds the hazard threshold level by 1.1 times for crude oil without dispersant, but by 6.8 times for crude oil premixed with dispersant.

In an attempt to identify and characterize the mechanisms affecting the generation of nanodroplets, subsequent studies focused on generation of airborne droplets by bursting of rising gas bubbles at the liquid-air interface (Sampath et al., 2019). Bubbles with different size ranges were injected into a seawater column covered by slicks of crude oil, pure dispersant, and a DOR 1:25 dispersant-oil mixture; the sensors mentioned above were used to measure nano- and micro-aerosol size distributions in both clean and ambient air environments. An order of magnitude increase in nanoparticle concentration was observed during bursting of bubbles larger than about $0.5 \mathrm{~mm}$ in slicks containing dispersant at a DOR of 1:25 of oil, and for a $50 \mu \mathrm{m}$ layer of pure dispersant, compared to smaller bubbles and tests not involving dispersant. These observations suggest that of the two mechanisms causing generation of airborne droplets during bubble bursting, namely jet droplets and film droplets (Veron, 2015), the nano-aerosols originated from breakup of the thin water film above the bubbles. In the micron range, all the bubble plumes generate micron-sized aerosols, but trends vary with bubble size and slick thickness, and the presence of dispersant does not cause an increase in the concentration of micro-aerosols compared to that for dispersant-free conditions. Based on their characteristic sizes, the micro-aerosols originated from jet droplets. In general, for the same surface contaminant, the microdroplet concentration decreases when the oil slick is thicker. A reduction of two orders of magnitude in the microdroplet concentration when medium and small bubbles burst in a thick $(500 \mu \mathrm{m})$ surface slick of crude oil is particularly striking.

Another study involving slicks of crude oil and oil-dispersant mixtures at DORs of $1: 25$ and $1: 100$ focused on the chemical composition of airborne PM2.5 particles (Afshar-Mohajer et al., 2020). These measurements included chemical analysis by gas chromatography and mass spectrometry, as well as use of a cascade impactor for size-fractioning of the particles. Results show that the total PM2.5 concentration released from the DOR 1:25 slick is about nine times higher and the oil content in them is about 2.4 times higher than those for pure crude oil. For particles smaller than $220 \mathrm{~nm}$, the crude oil concentrations for DOR 1:25 and 1:100 are about six and three times higher, respectively, than those for pure crude oil.

Several other studies involving aerosolized oil should also be mentioned. First, the generation of airborne droplets when raindrops impact oil slicks is discussed in Murphy et al. (2015). They show that the presence of oil slicks and dispersant alter the splashing and aerosol generation processes, and that the number of microdroplets increases both with oil layer thickness and with addition of dispersants. Second, M. Li et al. (2019) apply a wave-effect-resolving LES to simulate the transport of oil droplet aerosols by wind over surface waves in the marine atmospheric boundary layer. They show that wind considerably enhances oil droplet suspension and both vertical and lateral spreading, and that the spatial distribution of aerosols exhibits significant streamwise variations. Finally, Almeda et al. (2018) show that oil spills and dispersants can increase harmful algal blooms (HABs) and their associated toxins in the upper water column. Hence, in addition to risks associated with aerosolization of oil, changes to the resulting airborne toxins should also be considered if and when $\mathrm{HABs}$ are present.

\section{NEAR-FIELD PROCESSES: PLUME FORMATION AND DYNAMICS}

Above the primary bubble and droplet breakup zone, a buoyant plume of gas, oil, and entrained water forms and rises through the density-stratified ocean water column (Socolofsky et al., 2016; Boufadel et al., 2020). Depending on the water depth and stratification, the plume may pass through a level of neutral buoyancy, be arrested in its vertical ascent, and form a lateral intrusion layer (Socolofsky et al. 2011). During the Deepwater Horizon incident, this lateral intrusion was the basis of the subsea plume of oil and dissolved hydrocarbons at about $1,000 \mathrm{~m}$ 
water depth that extended for many kilometers (Gros et al., 2017; Hazen et al., 2010; see section on The Deep Plume and Intrusion Layer). Above the intrusion layer, gas bubbles and oil droplets may continue to rise at individual terminal rise velocities and advect downstream with the local currents (Gros et al., 2017; Dissanayake et al., 2018). Eventually, oil and gas either fully dissolve, impact the seafloor of the continental slope, or reach the ocean surface (Lindo-Atichati et al., 2014). Surfacing volatile compounds evaporate into the atmosphere (DeGouw et al., 2011; Le Hénaff et al., 2012; Gros et al., 2017), whereas residual oil creates surface slicks and interacts with surface mixing processes (see section on SmallScale Near-Surface Circulation Processes).

The near-field dynamics encompass a lateral region of up to a few kilometers' distance from the release, within which the vertical plume and potential intrusion layer formation are contained, and larger gas bubbles and oil droplets rise to the sea surface. Outside the near-field region, spatial and temporal variability of ocean currents becomes important (as discussed in sections below on Coastal to Offshore Linkage, Circulation, and Transport and The Deep Plume and Intrusion Layer).

Two main classes of models have been applied to the evolution of the near-field oil and gas plume (Socolofsky et al., 2016; Boufadel et al., 2020). Computational fluid dynamics (CFD) models based on the LES approach were developed to simulate the complex, unsteady interaction of the oil and gas with the surrounding seawater explicitly and in detail. These models treat the oil droplets and gas bubbles in two main ways. Oil droplets and gas bubbles may be treated as a continuous distribution, allowing for larger-scale simulations (Yang et al., 2016; Fabregat et al. 2016a,b). Alternatively, individual bubbles or droplets can be tracked, allowing finer details to be revealed, but at limited scale (Fraga et al., 2016). CFD models also show the important influence of Earth's rotation on near-field plume dynamics that affect both entrainment rates and detrainment levels.

Integral plume models, which model plume dynamics as an entity, use a cross-sectionally averaged velocity profile and solve for the variation of the flow rate, trajectory, plume width, and other plume parameters through a set of conservation equations (Johansen, 2003; Zheng et al., 2003; Dissanayake et al., 2018). These models are much less computationally expensive; hence, they lend themselves to rapid, full-scale modeling, so that predictions can be available in a matter of hours for making rapid forecasts (Barker et al., 2020). These models were extended recently to handle arbitrary bubble and droplet size distributions and to track the real-fluid equations of state and the dissolution of individual components of the oil and gas mixtures (Gros et al., 2016, 2017, 2018; Dissanayake et al., 2018). One example is the Texas A\&M Oilspill Calculator (TAMOC), an open-source model available from Github (Dissanayake et al., 2018). Because these models are designed to handle the real-world scale of a blowout, Lagrangian ${ }^{3}$ particle-tracking models for the far field (from a few to many kilometers away) were coupled offline to such integral models to simulate the Deepwater Horizon spill (North et al., 2011, 2015; Paris et al., 2012; Lindo-Atichati et al., 2016; French-McCay et al., 2018; Perlin et al., 2020), as well as dynamically coupled to one another (Vaz et al., 2019). These models can track both the liquid oil droplets and the passive tracers associated with dissolved hydrocarbon in both the near-field plume and the subsea lateral intrusion (Bracco et al., 2020).

Several laboratory, tank, and field experiments have been conducted in the last 10 years and used to test and validate both CFD and integral-type models of the near field. These studies include turbulence in bubble plumes (Lai and Socolofsky 2019; B. Wang et al., 2019), the dynamics of buoyant oil jets with and without dispersant injection (Murphy et al. 2016), and field experiments to track the evolution of gas bubbles associated with natural seeps (B. Wang et al., 2016, 2020).

The most important processes occurring in the near-field plume (see, e.g., Gros et al., 2016, 2017; Dissanayake et al., 2018) include (1) partitioning of the released fluids into separate gas and liquid petroleum phases, each containing a complex mixture of the released hydrocarbons; (2) primary breakup of the gas and liquid into bubbles and droplets; (3) dissolution of many lighter compounds from the gas- and liquid-phase particles; (4) the dynamical interaction of the buoyant plume with surrounding waters; (5) rapid vertical transport of the coherent plume into the intrusion layer (if present) or to the surface (in the case of shallower releases); (6) formation of intrusions that contain most of the dissolved hydrocarbons from the plume and some of the smaller oil droplets; and finally, (7) release of remaining gas bubbles and oil droplets from the intrusion layer. Near-field models aim to accurately predict phase separation, dissolution, and intrusion formation at scales up to a few kilometers (see also the section on The Deep Plume and Intrusion Layer). Intermediate and mesoscale (from a few up to a few hundred kilometers) and far-field (larger-scale) models need to be coupled within a region following intrusion formation. Because a large volume of hydrocarbons may enter such intrusions, far-field models need to track them, along with the droplets and the dissolved oil within and around them (e.g., Vaz et al., 2019). With respect to issues requiring further research, many questions remain about oil droplet size distribution (Faillettaz et al., 2021), as discussed above in the section on Microscale Physical (and Biophysical) Processes. Improvements in the time-varying estimation of initial droplet size distribution as live oil rises from the buoyant plume

${ }^{3}$ In a Lagrangian approach, observations and estimates are made at points that travel along with the flow. 
into the far-field water column will likely result in the next breakthrough. These estimates should be based on our understanding of multiphase and pressuredrop processes on the gas portion of the gas-saturated droplets (Griffiths, 2012; Socolosky et al., 2016; Vaz et al., 2020; Malone et al., 2020; Faillettaz et al., 2021), their evolution through partitioning and degassing during oil ascent in the water column (Gros et al., 2016; Jaggi et al., 2017, 2020; Pesch et al., 2018) and biodegradation (Joye et al., 2016b), and on the acquired knowledge of the effect of subsea dispersant injection (Paris et al., 2012, 2018; French-McCay et al., 2019).

\section{SMALL-SCALE, NEAR-SURFACE CIRCULATION PROCESSES}

Predicting the distribution of oil, buoyant plastics, flotsam, and marine organisms near the ocean surface remains a fundamental problem of practical importance. Work on this topic during GoMRI is summarized here, with an emphasis on the accumulation of floating material into highly concentrated streaks on horizontal scales from a few meters to tens of kilometers. A more detailed review of this topic is available in D'Asaro et al. (2020).

Prior to the GoMRI period, two new paradigms for surface distributions had emerged: one for the larger scales, emphasizing the importance of submesoscale (hundreds of meters to tens of kilometers) frontal dynamics, and the other for the smaller scales, emphasizing the importance of wind-surface-wave-driven Langmuir turbulence, ${ }^{4}$ with a broad transition between the two occurring near $100 \mathrm{~m}$. The small-scale motions are non-geostrophic, they are fully threedimensional (especially at the smallest scales), and they involve substantial vertical motions that are largely confined to the near-surface mixed layer. Such motions cause both convergence and divergence of water at the surface, leading to the concentration (and sometimes subduc- tion) of any floating materials. Pollutants, including oil, together with nutrients, Sargassum algae, larvae, and low-salinity waters of river origin therefore tend to accumulate along submesoscale fronts that are characterized by strong lateral convergence (Huntley et al., 2015; Choi et al., 2017). Such fronts may be riverinduced and thus represent a conduit that links the coastal to the open ocean, and they are key to both alongshore and cross-shore transport (Androulidakis et al., 2018) and to connectivity among coastal areas distant from one another. The importance of submesoscale motion in winter was accentuated away from the Mississippi River outflow, with perhaps the primary unanticipated result near the outflow being the remarkable and controlling influence of the associated freshwater anomalies and their expression at the submesoscale, quite likely independent of season, though dependent on river outflow rate.

In the open ocean, the Loop Current and its detached eddies (with diameters of 100-200 km) and submesoscale circulations all interact and contribute to the spreading of the riverine discharge offshore. In the northern Gulf of Mexico, submesoscale circulations are prevalent at the ocean surface not only in winter, as found in other basins, but also in summer, due to the amplification of the frontogenetic tendency associated with the abundant low-salinity water discharged by the Mississippi River system (Luo et al., 2016; Barkan et al., 2017).

Rapid progress in studying these processes has resulted from the combination of high-resolution numerical modeling tools, mostly developed before GoMRI, and new observational techniques developed during GoMRI (Mensa et al., 2018). Massive deployments of inexpensive and biodegradable satellite-tracked surface drifters combined with aerial tracking of oil surrogates (drift cards) enabled simultaneous observations of surface ocean velocities and dispersion over scales of $10 \mathrm{~m}$ to tens of kilometers. Surface current maps produced by ship-mounted radar and aerial optical remote sensing systems, combined with traditional oceanographic tools, enabled a set of coordinated measurement programs that supported and expanded these new paradigms (Özgökmen et al., 2018; see also sections below on Offshore Circulation and Transport and Coastal to Offshore Linkage, Circulation, and Transport).

Submesoscale fronts caused floating material to both accumulate at fronts and disperse as they evolved, leading to higher localized concentrations in some places, but nevertheless increased overall larger-scale dispersion (D'Asaro et al., 2018). Analyses of both model results and observational data confirmed the distinct submesoscale dynamics of this process and the complexity and variability of the resulting surface concentration fields. Existing analytical and modeling tools could be developed into predictive models for submesoscale processes on a statistical basis, but prediction of individual submesoscale features will likely always remain limited by the data that can be obtained and the transient nature of the processes involved. Away from fronts, measured rates of accumulation of material in and beneath surface windrows was found to be consistent with Langmuir turbulence, but highly dependent on the rise rate of the material and thus, for oil, on the droplet size (Chen et al., 2016b). Models of this process were developed and tested and could be further developed into predictive tools (Sullivan and McWilliams, 2018). Both the submesoscale and Langmuir processes are sensitive to coupling with wind and surface waves as well as air-sea interaction processes, further complicating forecasting of the submesoscale distributions of floating materials. In addition, competition between Langmuir turbulence and submesoscale dynamics has been found

\footnotetext{
${ }^{4}$ Langmuir turbulence is the near-surface three-dimensional turbulent motion associated with Langmuir circulation cells. They are long, shallow overturning cells that form when surface currents interact with wind-driven waves.
} 

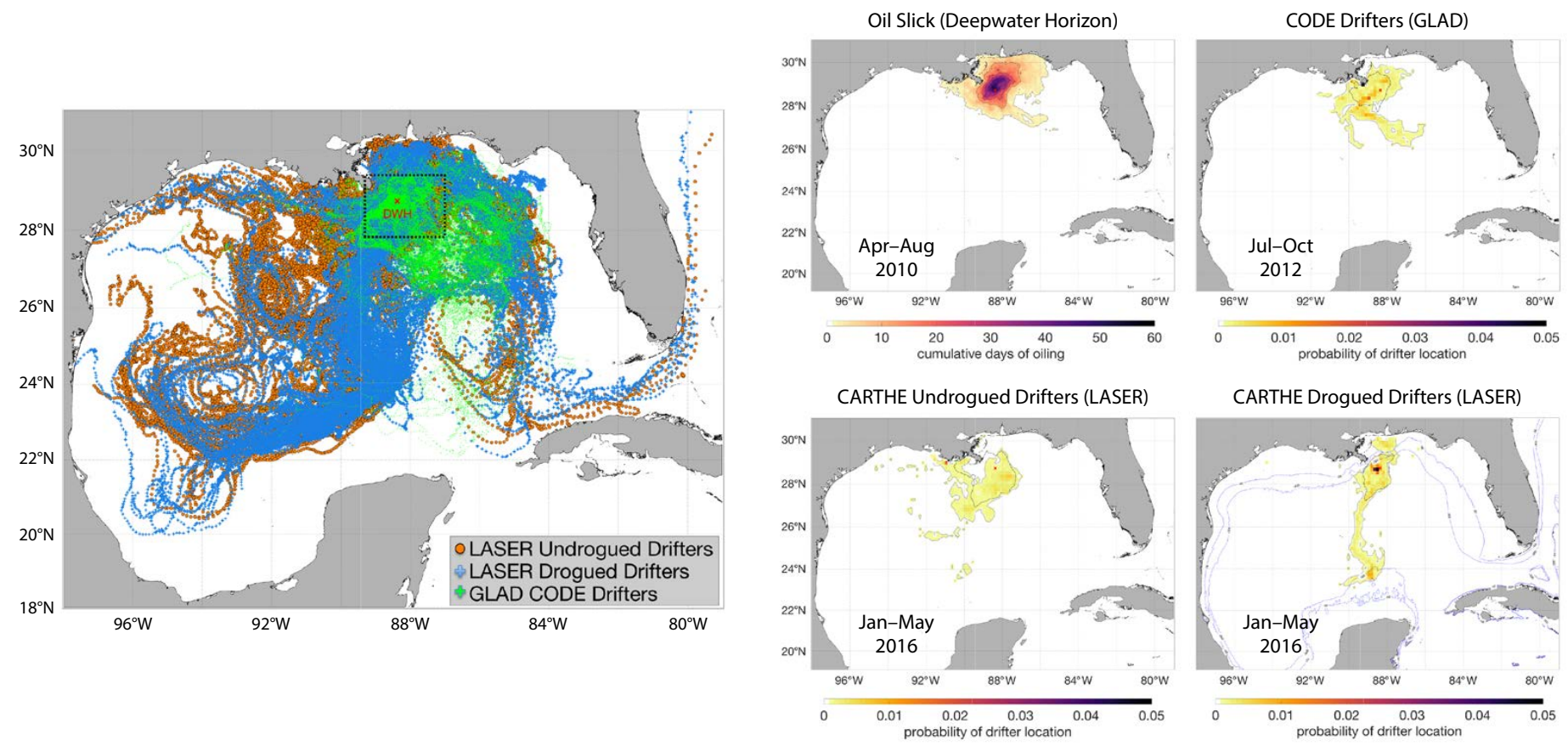

CARTHE Drogued Drifters (LASER)

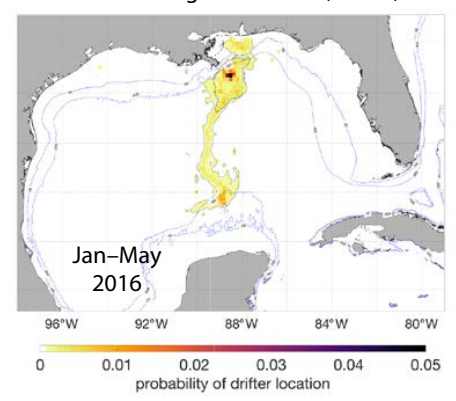

FIGURE 3. (left panel) Cumulative spatial span of all Consortium for Advanced Research on Transport of Hydrocarbon in the Environment (CARTHE) drifters deployed in the northern Gulf of Mexico. (right panels) Oil coverage from the DWH event compared to drifter density from the Grand LAgrangian Deployment (GLAD) and LAgrangian Submesoscale ExpeRiment (LASER), with drogued and undrogued drifters shown separately. From Novelli et al. (2020)

to be quite important, if somewhat intermittent in space and time. Finally, and importantly, boundary layer turbulence due to an external source, such as wind or convection, can couple to the submesoscale dynamics via a turbulent thermal wind effect ${ }^{5}$ on the cross-front balance between the pressure gradient and the Coriolis force. Here, both the turbulent intensities and the submesoscale frontogenesis can be affected. The interactions discussed here provide important directions for future research.

\section{OFFSHORE CIRCULATION AND TRANSPORT}

When hydrocarbons from a deep oil spill reach the surface, they are strongly influenced by air-sea forcing, including surface dispersion by ocean currents, mixed layer dynamics, wind, and waves, all of which vary greatly over time and with weather conditions (Judt et al., 2016). The impacts of processes operating over a very wide range of spatial and temporal scales must therefore be taken into account when responding to an oil spill. Advection of the oil by large-scale flows (tens to hundreds of kilometers, for example, the Loop Current and associated eddies) provides a first-order description of the oil's trajectory, but small-scale (100 m to $10 \mathrm{~km}$ ) processes critically impact transport and mixing in the upper ocean. In particular, Stokes driff ${ }^{6}$ from surface waves and Ekman transport from wind stress combine to form the near-surface currents that advect the oil. The depth of such currents is controlled by boundary layer turbulence, including Langmuir circulations, that are driven by air-sea fluxes and surface waves. These processes create complex distributions of material and produce very different patterns of the oil spread than would be obtained considering only the larger-scale flows.

During GoMRI, the Gulf of Mexico's near-surface circulation was investigated by deploying thousands of biodegradable Lagrangian drifters, notably in the
Grand LAgrangian Deployment (GLAD) and the LAgrangian Submesoscale ExpeRiment (LASER) (Novelli et al., 2017) of the Consortium for Advanced Research on Transport of Hydrocarbon in the Environment (CARTHE). Lagrangian deployments are naturally suited for studies of the tracer transport problem because they do not suffer from the sampling and averaging errors of fixed and ship-based measurements, and they continue to sample the velocity field long after the cruise period ends, even under adverse conditions. Cumulative trajectories from CARTHE's sampling of the Gulf of Mexico are shown in Figure 3. After being released near the DWH site, drifters dispersed across almost the entire basin (with the exception of continental shelves) in three to six months. A comparison with the oil concentration from the DWH event shows that the GLAD (summer) and undrogued LASER (winter) drifters have a very similar spatial distribution to that of oil from the DWH spill, while

\footnotetext{
${ }^{5}$ When a balanced front is disturbed by turbulent mixing, a secondary circulation with flow in the cross-front and vertical directions develops. The horizontal convergence associated with the secondary circulation intensifies development of the front (see, e.g., Crowe and Taylor, 2018)

${ }^{6}$ Stokes drift is the systematic net motion of material particles in a surface wave field caused by the difference between the Lagrangian and Eulerian average velocities, effectively the difference in particle velocities between the top and the bottom of their approximately circular trajectories.
} 

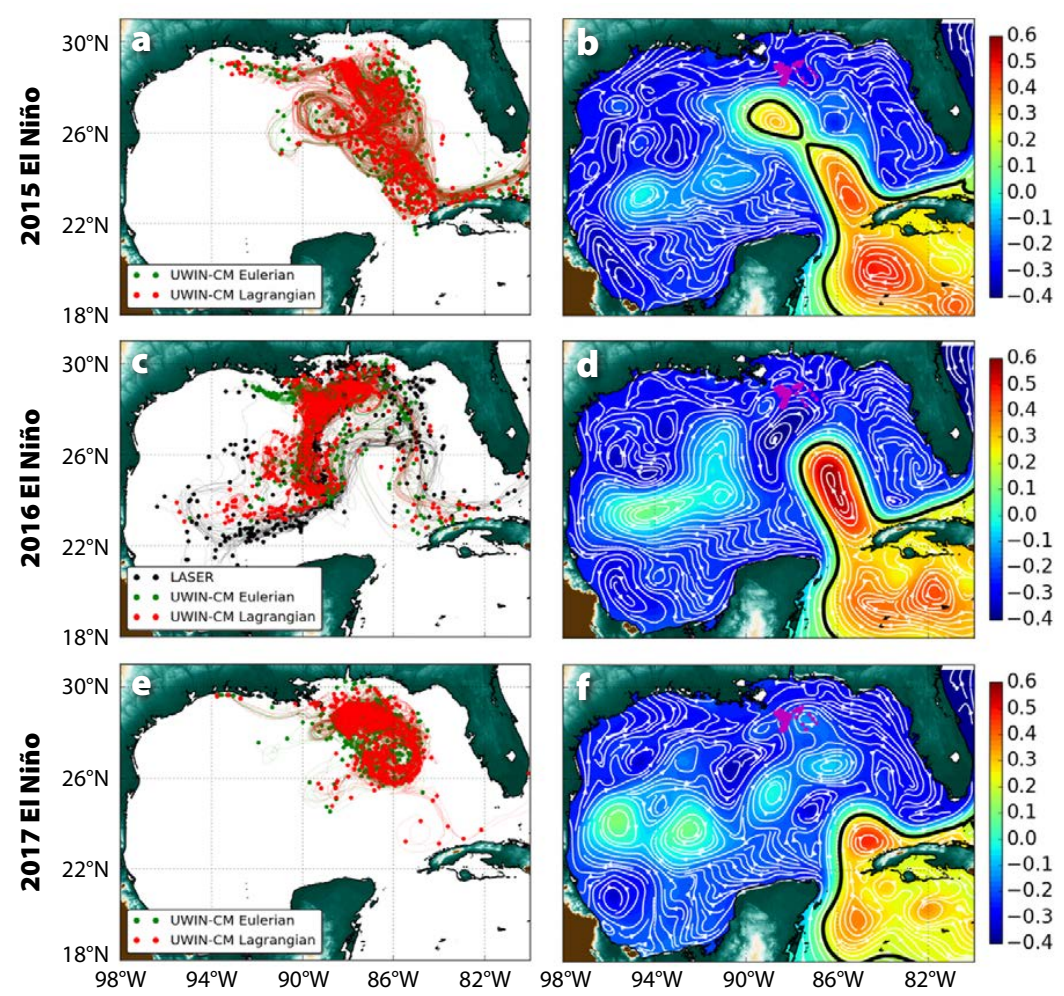

Oil Spill Area
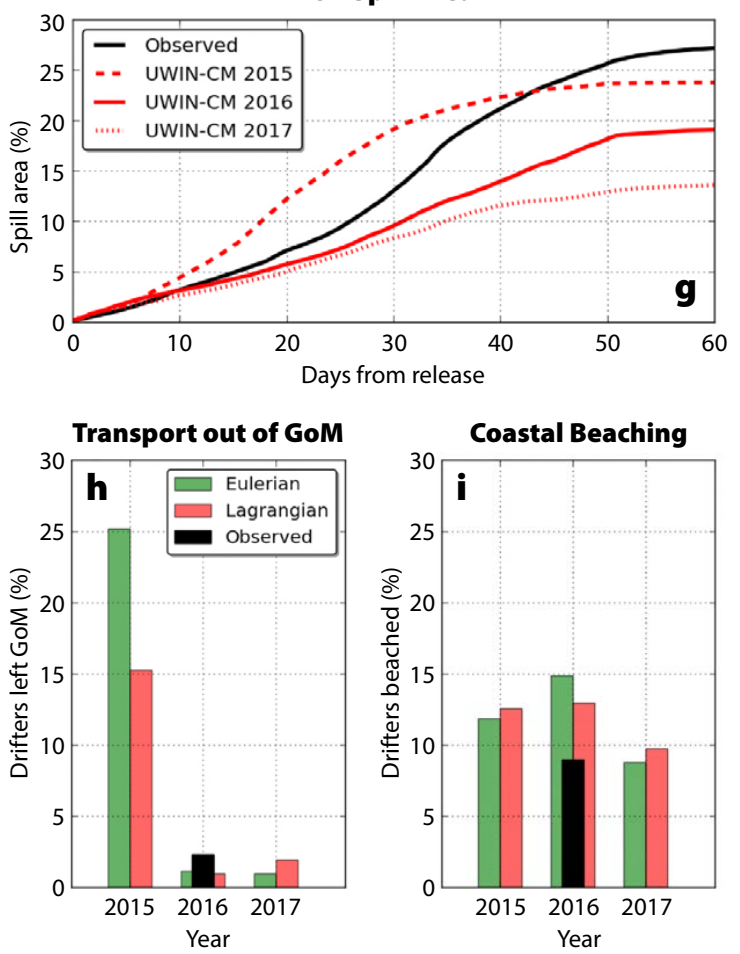

FIGURE 4. (LEFT PANELS) Unified Wave Interface-Coupled Model (UWIN-CM) simulations of Gulf of Mexico (GoM) circulation. Panels (a), (c), and (e) show simulated Eulerian (green) and Lagrangian trajectories (red), and panels (b), (d), and (f) illustrate average sea surface height (SSH, in colors) and surface circulation (streamlines, in white) between January 21 and March 29 in 2015, 2016, and 2017. Panel (c) also shows observed LASER trajectories (black). Initial drifter locations are indicated with magenta dots near the DWH site. The Loop Current is shown by the $17 \mathrm{~cm}$ SSH contour (thick black line). (RIGHT PANELS) Simulated and observed characters of the oil spill: (g) evolution of oil spill area, (h) transport out of the Gulf, and (i) coastal beaching for 2015-2017 (data supplied by author Chen).

drogued drifters from LASER tend to follow a mesoscale filament southward all the way to the Mexican shelf break (Haza et al., 2018, 2019). This led to the conclusion that upper-ocean vertical shear and seasonality play important roles in transport patterns. It is important to keep in mind that, over the long term (weeks, months), drifters differ from oil in many ways, in that they do not evaporate or undergo other complex transformations.

Coupled atmosphere-wave-ocean models can be used in conjunction with the drifter measurements. Figure 4 displays model-simulated drifter transport pathways for the winters of 2015, 2016, and 2017 from the Unified Wave InterfaceCoupled Model (UWIN-CM; Chen et al., 2013; Chen and Curcic, 2016) with both atmospheric and oceanic components fully coupled to the surface wave model. Thus, it allows for an accurate explora- tion of wind-wave-current coupling and the influence of Stokes drift on surface material transport. The transport patterns are modulated to a large degree by the structure of the Loop Current, whose northern intrusion varied greatly during 2015-2017. These three years correspond to the 2015-2016 El Niño and the subsequent weak La Niña in 2017. The area of the spill and the transport of simulated drifters out of the Gulf through the Florida Straits both depend on the structure of the Loop Current, while coastal beaching remains more or less the same across these three years and must therefore depend on smaller-scale features of the circulation. The UWIN-CM simulations and the LASER drifter data for 2016 show reasonable agreement. Windinduced surface waves enlarge the area of spilled oil in general (denoted as Lagrangian vs. Eulerian in Figure 4h,i), which can affect how oil and drifters interact with the Loop Current. The simulated Lagrangian drifters spread faster over a larger area than the simulated Eulerian drifters, which remain more concentrated near the Loop Current and may be transported out of the Gulf. Overall, Figure 4 provides a rather striking picture of multiscale air-sea interaction, especially the interannual variability of surface transport patterns in the entire Gulf of Mexico.

Near-field, short-term dispersion is, however, more important than long-term transport for guiding a spill response effort. To this end, local and real-time assimilation of data to initialize and constrain the models, using adequate data sources and good assimilation schemes, is critical for a good forecast. For example, the upper left panel of Figure 5 shows Lagrangian coherent structures (LCSs) ${ }^{7}$ computed from the Navy Coastal Ocean

${ }^{7}$ Lagrangian coherent structures are systematic patterns of circulation within a turbulent flow field that lead to the formation of coherent patterns in the distribution of tracer materials (e.g., blobs and streaks). 
Model (NCOM) during the GLAD expedition. There is a significant mismatch with a concurrent chlorophyll image collected by the Moderate Resolution Imaging Spectroradiometer (MODIS). In fact, Jacobs et al. (2014) found that LCSs computed from satellite-altimeterderived geostrophic velocity directly, without assimilating into $\mathrm{NCOM}$, initially were in better agreement with this chlorophyll image. This implied the need for modification of procedures followed during data assimilation into NCOM when there was a scarcity of altimeter tracks over the Gulf of Mexico. After the procedures were modified, much better agreement was attained (lower left panel of Figure 5). Assimilation of data from the large numbers of drifters further improved model performance. By developing appropriate Lagrangian data assimilation algorithms, Carrier et al. (2014) and Muscarella et al. (2015) found that the assimilation of even a small number of (GLAD) drifter trajectories improved NCOM realism (right panels of Figure 5). In particular, for oil spills, drifters can be deployed repeatedly right on top of the spill to track it during nighttime and bad weather, as opposed to hoping that satellite tracks will coincide with the spill's location. However, because results at scales that are not constrained by data become chaotic and do not have useful forecasting value, high-resolution modeling requires high-resolution data. By themselves, however, high-resolution models may still provide insight into the potential ensemble of possible flow characteristics, and on the importance of the various physical processes at play.

It should be noted that not all of the oil from the Deepwater Horizon blowout reached the surface. A substantial percentage of the oil was entrained into deep plumes and biodegraded therein. The behavior of such plumes is not easily predictable, because of lack of knowledge of the deep circulation and how it is modified by diapycnal mixing. This issue is discussed in detail in section below on The Deep Plume and Intrusion Layer.

\section{COASTAL TO OFFSHORE LINKAGE, CIRCULATION, AND TRANSPORT}

Under the auspices of GoMRI, much has been learned about transport processes in the Gulf of Mexico along the very important land-ocean continuum, from the coast, estuaries, wetlands and shelves to the deep ocean interior. An in-depth synthesis of this research will be available in a forthcoming paper by author Justić and colleagues. Advances have been particularly outstanding with respect to the tools and methodologies available for collecting, analyzing, and synthesizing data and for simulating coastal to offshore linkages and transport. Taken together, these improvements enable better shortand long-term forecasting capabilities as well as better-informed decisions for coastal resource and ecosystem management. Below, we summarize major progress in a geographical progression, moving from the land-ocean boundary to the open ocean.

Observations, laboratory experiments, and data analyses have all contributed to a better understanding of estuarine and coastal hydrodynamics and associated transport of freshwater, sediments, nutrients, and pollutants (Zheng and Weisberg, 2010; Beland et al., 2017; Valentine and Mariotti, 2019). The unstructured grid models that are now available are better equipped to simulate the complex coastal geometries of marshes, wetlands, and estuaries, and their multiscale time variabilities (Justić and Wang, 2014; White et al., 2019c). There are also improvements in model-
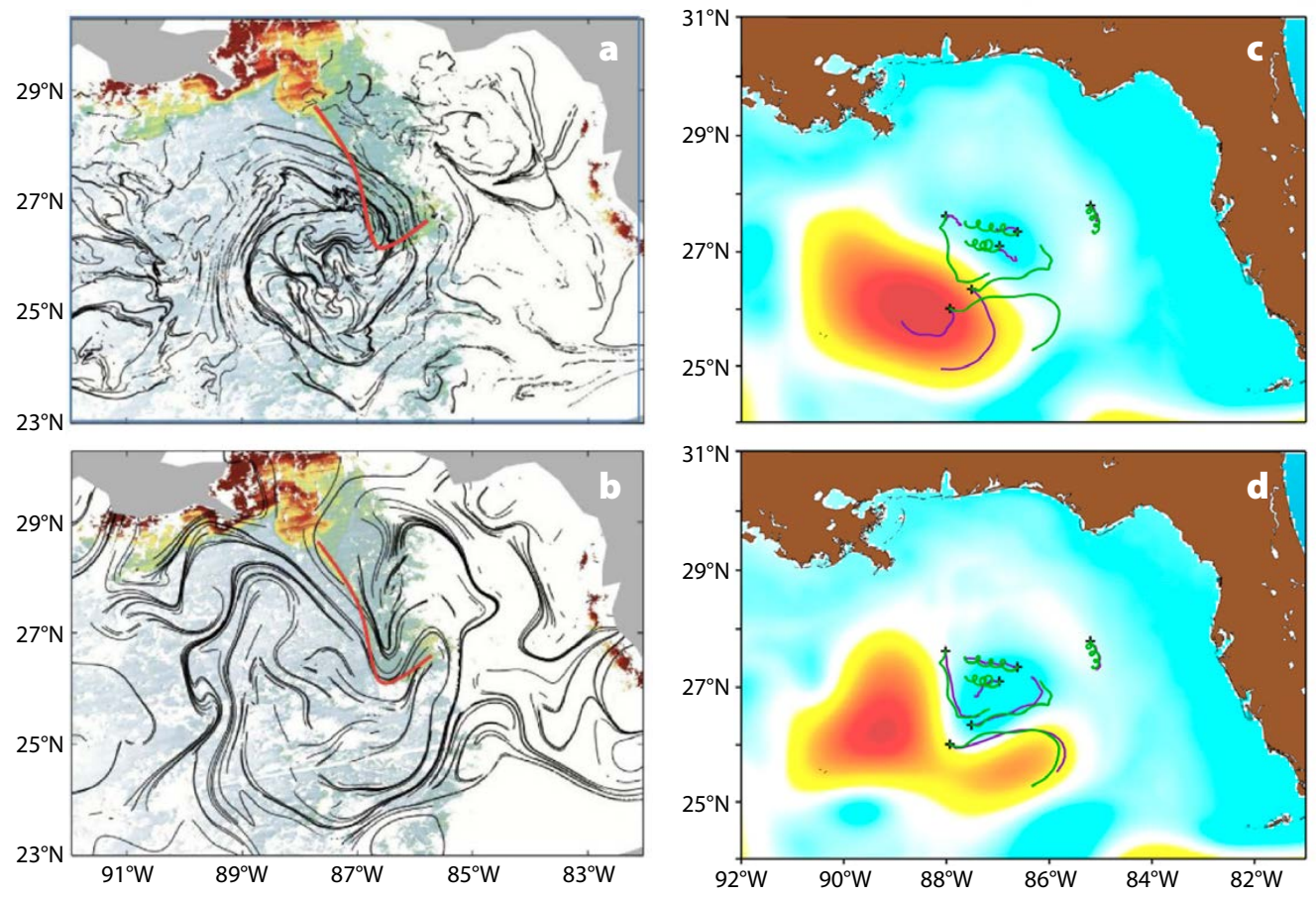

FIGURE 5. Improvement of model predictions using data assimilation. (left panels) Navy Coastal Ocean Model (NCOM) simulation of particle tracks with superimposed sea color images, both without (a) and with (b) assimilation of altimeter data. Note the improved alignment of the flow field with the long filamentary "intrusion." From Jacobs et al. (2014) (right panels) Further improvement of NCOM simulations, both without (c) and with (d) assimilation of GLAD drifter data. Note the improved alignment of fronts with drifter tracks. From Muscarella et al. (2015) 
ing of river-estuarine coupling, and there is widespread assimilation of operational meteorological or reanalysis products. For example, we have come to realize that river diversions influence estuary dynamics within $20-25 \mathrm{~km}$ from the diversion, but they may not significantly impact the transport of oil slicks further offshore (H. Huang et al., 2011). However, largescale sediment diversions have the potential to influence estuarine flushing further than $60 \mathrm{~km}$ from the diversion sites, albeit with significant ecological tradeoffs associated with estuarine freshening (Cui, 2018). The emerging consensus on the use of river diversions in the case of DWH is that they were ineffective in achieving their primary objective to push the oil away from coastal wetlands and rather resulted in unanticipated deleterious ecological impacts (Westerholm et al., 2021, in this issue). This was due to the complex interaction of Mississippi River plume waters with the oil that was moving onshore (Kourafalou and Androulidakis, 2013), interaction that was dependent on the offshore currents over the shelf (dominated by wind and river discharge variability) and on the open sea (dominated by the Loop Current and associated eddies).

In the past 10 years, we have come to appreciate the importance of both horizontal and vertical resolution in coastal and regional models. High vertical resolution is required to achieve good representation of the Ekman layers at the ocean surface and near the seafloor (within which currents are diminished and rotated by the joint effects of viscous drag and the Coriolis force; Weisberg et al., 2014) and to properly capture diapycnal $^{8}$ mixing in both coastal areas and in the open ocean (Bracco et al., 2018). Furthermore, at the land-ocean interface, especially in the presence of barrier islands and beaches, representation of flooding and drying is important and should be directly included in the vertical coordinate system (Zheng and Weisberg, 2012; Weisberg et al., 2014). High-resolution coastal and regional models should pay close attention to the representation of inlets and islands (Androulidakis et al., 2019, 2020) and the effects of wind-wave-current coupling on transport due to Stokes drift (Curcic et al., 2016), whose influence varies depending on water depth. Stokes drift did indeed contribute to the deposition of oil on beaches following the DWH spill (Le Hénaff et al., 2012).

Finally, major refinements of transport modeling tools have improved our ability to predict ecosystem connectivity (the interrelationships within and between species in different places) and oil transport. On the ecosystem side, we have made much progress in understanding and predicting movement of adult and juvenile fish, coral larvae, and other taxa (Cardona et al., 2016; Ainsworth et al., 2018; Martin et al., 2020; Paris et al., 2020) and in estimating connectivity among coastal habitats, shelves, and estuarine wetlands of the Gulf of Mexico. Regarding the transport of oil, the initial surface trajectory models used as part of the rapid response to the DWH spill have been augmented by simulations that include oil droplet size variations and subsea chemical dispersant applications, using both Eulerian ${ }^{9}$ and Lagrangian approaches. Through modeling and observational efforts, we have better quantified the important role that Stokes drift played in modifying the dispersion of the oil toward both the coastline and open waters. We have also realized that river diversions have limited effectiveness in keeping the oil away from the estuaries (H. Huang et al., 2011), that the Mississippi River plume exerts buoyancy-driven effects on the oil that may vary significantly in space (Dagestad et al., 2018; Hole et al., 2019), and that there is an elevated risk of remobilization of oil stored in shallow sediments during energetic storms (Zengel et al., 2015).

Challenges remain in both the observational and the modeling realms. They pertain to the high computational costs associated with current algorithms for simulating wetlands, estuaries, riverestuary coupling, and shelf exchanges at the high spatial resolution needed. The mechanisms controlling wave-current interactions in river deltas and the relative importance of atmospheric fluxes, riverine fluxes, and ocean circulations also remain uncertain, especially in rough weather conditions. When investigating transport across and along coastal areas, better coordination of observational and modeling efforts should be strongly encouraged; the uncertainties in atmospheric forcing and boundary conditions (wind stress and heat flux) should be quantified and, if possible, reduced; and simulations of circulations around barrier islands and beaches should have longer time horizons. A multiscale approach, using multiple models at different scales simultaneously through nesting techniques, is recommended. Such an approach should be augmented by an in-depth exploration of mesoscale-submesoscale linkages and by an investigation of model dependency on vertical discretization. Riverine forcing should be better monitored and accurately modeled not only to improve forecasting and response planning in the event of another spill but also to better monitor and manage the Gulf marine ecosystem. In this regard, more observations are needed to constrain how species behavior contributes to coastal-open ocean ecological linkages. Finally, further model intercomparison studies using different hydrodynamic and oil (particle-tracking) models should be prioritized in order to improve model formulations for oil-tracking purposes.

\footnotetext{
${ }^{8}$ Mixing in the deep ocean occurs predominantly along isopycnals (the approximately horizontal surfaces of constant density). A much smaller but nevertheless extremely important amount of mixing occurs across or between density surfaces, known as diapycnal mixing.

${ }^{9}$ In an Eulerian approach, observations and estimates are made at fixed points in space, whereas in a Lagrangian approach they are made at points that travel along with the flow.
} 
In summary, much progress in understanding transport processes has been achieved in the past 10 years. To sustain such growth and amplify its benefits, we recommend the development of a suite of appropriately scaled ocean circulation and wave models that are capable of strategically zooming into the key components of the land-ocean continuum, and that are supported by observing arrays designed to target process understanding, data assimilation, and model validation.

\section{THE DEEP PLUME AND INTRUSION LAYER}

As mentioned in the section on Offshore Circulation and Transport, not all the oil from the DWH blowout reached the surface. A significant proportion (up to $50 \%$ ) was entrained into deep subsurface plumes or intrusion layers that traveled laterally at approximately 1,200 m depth along the continental slope and was biodegraded therein. The largest and best sampled of these was discovered through in situ measurements in August 2010 (Camilli et al., 2010; Diercks et al., 2010; Kessler et al., 2011). Since its discovery, the scientific community has made significant progress in understanding and modeling the transport, evolution, and fate of the hydrocarbons trapped in the plume (Gros et al. 2017; also reviewed in Bracco et al., 2020). However, a major challenge for data assimilative ocean models that seek to predict the circulation of the Gulf of Mexico below $1,000 \mathrm{~m}$ depth remains due to the absence of any continuous monitoring systems that extend below the ocean's surface (Cardona and Bracco, 2016).

The deep tracer release experiment by the GoMRI-funded Gulf of Mexico Integrated Spill Response (GISR) Consortium was designed to address the limited knowledge of key physical variables below the mixed layer by providing an estimate of interior diapycnal mixing. In August 2012, Ledwell and collaborators from the GISR Consortium injected a streak of trifluoromethyl sulfur penta- fluoride (CF3SF5) at about 1,100 m depth near the DWH site to quantify its dispersion (Ledwell et al., 2016). The tracer was sampled one week, four months, and finally one year after its release. A turbulent diapycnal eddy diffusivity greater than $4 \times 10^{-4} \mathrm{~m}^{2} \mathrm{~s}^{-1}$ was estimated for the boundary region (close to the seafloor of the continental slope), which is very high relative to typical values for the deep ocean interior $\left(<10^{-5} \mathrm{~m}^{2} \mathrm{~s}^{-1}\right)$, but lower values were found for the interior of the plume. The main conclusion from this exercise was that diapycnal mixing at mid-depth in the northern Gulf of Mexico is much greater near the continental slope than in the interior and that homogenization of a tracer released near the continental slope proceeds much faster than in the open ocean (Polzin et al., 2014). These effects are not yet included in operational models.

Bracco et al. (2016) examined the generation mechanisms and mixing implications of mesoscale and submesoscale circulations near the ocean floor. They showed that the diapycnal mixing coefficient increased near to the continental slope compared to the interior, as observed in the tracer data, and also to the west of the Mississippi Fan, where submesoscale processes were more abundant compared to De Soto Canyon. Later, the contribution of horizontal and vertical model resolutions to the representation of diapycnal diffusivities and the advection of a passive tracer was further explored (Bracco et al., 2018, 2019). Results suggested that a deep spill that occurred to the west of the Mississippi Fan would impact the continental slope far more extensively than did the DWH spill by mixing the hydrocarbons more rapidly and distributing them over a larger area in a few months (Rogener et al., 2018).

In terms of hydrocarbon modeling, major improvements made include better estimations of the initial droplet size (Bandara and Yapa, 2011; Paris et al., 2012; Johansen et al., 2013; Zhao et al., 2014a,b, 2016; Aman et al., 2015; C. Li et al., 2017; Malone et al., 2018;
Pesch et al., 2020a) and more accurate representations of plume dynamics (Paris et al., 2012; Lindo-Atichati et al., 2016) and of the pressure-dependent process of internal degassing in two-phase droplets (Pesch et al., 2018, 2020b). Focusing here on the representation of the lateral plume evolution in the far field, state-of-the-art models simulate the advection of individual droplets by the velocity field generated in hydrodynamic models (North et al. 2011, 2015; Paris et al., 2013; Perlin et al., 2020) and the dissolution and biodegradation of gas and oil droplets as functions of the local environmental and biogeochemical conditions (Chen et al., 2016a; Joye et al., 2016a,b). It is now also possible to realistically simulate droplet aggregation with both organic and inorganic matter and the subsequent settlement of the heavier aggregates on the seafloor (Khelifa et al., 2008; Zhao et al., 2016; Daly et al., 2016, 2020; Dissanayake et al., 2018; Vaz et al., 2020), and also to allow for the effect of subsea dispersant injection (Paris et al., 2012, 2018; FrenchMcCay et al., 2019).

With respect to issues requiring further research, many questions remain concerning the spatial and temporal evolution of flows in midwater and in the bottom boundary layer, and specifically how processes at scales of centimeters to hundreds of meters translate into large-scale transport impacts (Bracco et al., 2020). Improved theoretical understanding of ocean near-bottom dynamics is needed and could be achieved with a few years of targeted monitoring using acoustic Doppler current profilers (ADCPs) to quantify velocities and their variability, while the current generation of high-resolution, regional models could identify locations to prioritize for the observational efforts. Because detection and modeling of subsurface oil is difficult, advances will also emerge from the use of ensemble probabilistic modeling (Perlin et al., 2020) for guiding underwater remotely operated vehicles. Finally, intercomparison of modeling strategies (e.g., Socolofsky et al., 2015) should 
be prioritized to improve the predictions of deep plumes and the response trade-offs for any future deep-sea spills (Murawski et al., 2019).

\section{CONCLUSIONS AND KEY FINDINGS}

While the physical processes described above constitute dominant influences on the spatial distribution of materials including oil, a major discovery has also been the importance of the marine oil snow sedimentation and flocculent accumulation (MOSSFA) process, as described by Farrington et al. (2021) and Quigg et al. (2021), both in this issue. Here, physical, chemical, and biological processes interact to produce negatively buoyant particles that sink to the seafloor, countering the general tendency of oil to rise toward the surface. Further notable conclusions are:

- Major advances in understanding of pressure-induced processes on gassaturated oil and refinements of transport modeling tools have improved our ability to predict both ecosystem connectivity and oil transport.

- CFD models have shown the importance of Earth's rotation in nearfield plume dynamics that affect both entrainment rates and detrainment levels.

- Recent model improvements include high-resolution regional coupled atmosphere-wave-ocean modeling, riverestuarine coupling, ability to resolve surface and bottom Ekman layers, consideration of Stokes drift, and the widespread adoption of operational meteorological or reanalysis products.

- There is an emerging consensus that the use of river diversions in the case of DWH was ineffective in achieving its primary objective to push the oil away from coastal wetlands and, rather, that it resulted in unanticipated deleterious ecological impacts.

- River-induced fronts play important roles in alongshore and cross-shore transport, acting both as barriers to material transport and as convergence zones that guide transport along frontal lines.

- Advection of pollutants along pathways that link coastal areas and the open ocean is influenced by both mesoscale and submesoscale circulation features.

- Better understanding of the effects of multiscale atmosphere-wave-ocean coupling on ocean transport, on hourly to interannual timescales, can help improve prediction not only in the Gulf of Mexico but also elsewhere.

Under the auspices of GoMRI, important advances were thus made with respect to the tools and methodologies for collecting, analyzing, and synthesizing data and for simulating coastal to offshore and deep-sea linkages and transport. To sustain such progress, and amplify its benefits, we recommend developing and maintaining a regional forecasting system in order to be better prepared for any future oil spill events. It should be based on a suite of appropriately scaled ocean circulation, atmospheric, and wave models capable of strategically zooming in on the key components of the land-ocean continuum and should be supported by well-designed observing arrays that target process understanding as well as data assimilation and model validation. @

\section{REFERENCES}

Afshar-Mohajer, N., C. Li, A.M. Rule, J. Katz, and K. Koehler. 2018. A laboratory study of partic ulate and gaseous emissions from crude oil and crude oil-dispersant contaminated seawater due to breaking waves. Atmospheric Environment 179:177-186, https://doi.org/10.1016/ j.atmosenv.2018.02.017.

Afshar-Mohajer, N., M.A. Fox, and K. Koehler. 2019. The human health risk estimation of inhaled oil spill emissions with and without adding dispersant. Science of the Total Environment 654:924-932. https://doi.org/10.1016/j.scitotenv.2018.11.110.

Afshar-Mohajer, N., A. Lam, L.D. Chandrala, J. Katz, A.M. Rule, and K. Koehler. 2020. Impact of dispersant on crude oil content of airborne fine particulate matter emitted from seawater after an oil spill. Chemosphere 256:127063, https://doi.org/10.1016/ j.chemosphere.2020.127063.

Ainsworth, C.H., C.B. Paris, N. Perlin, L.N. Dornberger, W.F. Patterson III, E. Chancellor, S. Murawski, D. Hollander, K. Daley, I.C. Romero, and others. 2018. Impacts of the Deepwater Horizon oil spill evaluated using an end-to-end ecosystem model. PLOS ONE 13(1): e0190840, https://doi.org/10.1371/ journal.pone.0190840.

Aiyer, A., D. Yang, M. Chamecki, and C. Meneveau. 2019. A population balance model for large eddy simulation of polydisperse droplet evolution. Journal of Fluid Mechanics 878:700-739, https://doi.org/10.1017/jfm.2019.649.
Almeda, R., S. Cosgrove, and E.J. Buskey. 2018. Oil spills and dispersants can cause the initiation of potentially harmful dinoflagellate blooms ("red tides"). Environmental Science \& Technology 52:5,718-5,724, https://doi.org/10.1021/ acs.est.8b00335.

Aman, Z., C.B. Paris, E.F. May, M.L. Johns, D. LindoAtichati. 2015. High-pressure visual experimental studies of oil-in-water dispersion droplet size. Chemical Engineering Science 127:392-400, https://doi.org/10.1016/j.ces.2015.01.058.

Androulidakis, Y., V.H. Kourafalou, T. Özgökmen, O. Garcia-Pineda, B. Lund, M. Le Hénaff, C. Hu, B.K. Haus, G. Novelli, D. Guigand, and others. 2018. Influence of river-induced fronts on hydrocarbon transport: A multiplatform observational study. Journal of Geophysical Research Oceans 123(5):3,259-3,285, https://doi.org/ 10.1029/2017JC013514.

Androulidakis, Y., V.H. Kourafalou, M. Le Hénaff,

H. Kang, T. Sutton, S. Chen, C. Hu, and N. Ntaganou. 2019. Offshore spreading of Mississippi waters: Pathways and vertical structure under eddy influence. Journal of Geophysical Research: Oceans 124(8):5,952-5,978, https://doi.org/10.1029/2018JC014661.

Androulidakis, Y., V.H. Kourafalou, M. Le Hénaff, H. Kang, N. Ntaganou, and C. Hu. 2020. Gulf Stream evolution through the Straits of Florida: The role of eddies and upwelling near Cuba. Ocean Dynamics 70:1,005-1,032, https://doi.org/ 10.1007/s10236-020-01381-5.

Bandara, U.C., and P.D. Yapa. 2011. Bubble sizes, breakup, and coalescence in deepwater gas/oil plumes. Journal of Hydraulic Engineering 137:729-738, https://doi.org/10.1061/ (ASCE)HY.1943-7900.0000380.

Barkan, R., J.C. McWilliams, A.F. Shchepetkin, M.J. Molemaker, L. Renault, A. Bracco, and J. Choi. 2017. Submesoscale dynamics in the northern Gulf of Mexico: Part I. Regional and seasonal characterization and the role of river outflow. Journal of Physical Oceanography 47(9):2,325-2,346, https://doi.org/10.1175/JPO-D-17-0035.1.

Barker, C.H., V.H. Kourafalou, C. Beegle-Krause, M. Boufadel, M.A. Bourassa, S.G. Buschang, Y. Androulidakis, E.P. Chassignet, K.-F. Dagestad, D.G. Danmeier, and others. 2020. Progress in operational modeling in support of oil spill response. Journal of Marine Science and Engineering 8(9):668-723, https://doi.org/10.3390/ jmse8090668.

Beland, M., T.W. Biggs, D.A. Roberts, S.H. Peterson, R.F. Kokaly, and S. Piazza. 2017. Oiling accelerates loss of salt marshes, southeastern Louisiana. PLoS ONE 12(8):e0181197, https://doi.org/10.1371/ journal.pone.0181197.

Berenshtein, I., C.B. Paris, N. Perlin, M. Alloy, S. Murawski, and S. Joye. 2020. Invisible oil beyond the Deepwater Horizon satellite footprint. Science Advances 6(7):eaaw8863, https://doi.org/ $10.1126 /$ sciadv.aaw8863.

Boufadel, M.C., S. Socolofsky, J. Katz, D. Yang, C. Daskiran, and W. Dewar. 2020. A review on multiphase underwater jets and plumes: Droplets, hydrodynamics, and chemistry. Reviews of Geophysics 58(3):e2020RG000703, https://doi.org/10.1029/2020RG000703.

Bracco, A., J. Choi, K. Joshi, H. Luo, and J.C. McWilliams. 2016. Submesoscale currents in the northern Gulf of Mexico: Deep phenomena and dispersion over the continental slope. Ocean Modelling 101:43-58, https://doi.org/10.1016/ j.ocemod.2016.03.002.

Bracco, A., J. Choi, J. Kurian, and P. Chang. 2018. Vertical and horizontal resolution dependency in the model representation of tracer dispersion in the northern Gulf of Mexico. Ocean Modelling 122:13-25, https://doi.org/10.1016/ j.ocemod.2017.12.008. 
Bracco, A., G. Liu, and D. Sun. 2019. Mesoscalesubmesoscale interactions in the Gulf of Mexico: From oil dispersion to climate. Chaos, Solitons \& Fractals 119:63-72, https://doi.org/10.1016/ j.chaos.2018.12.012.

Bracco, A., C.B. Paris, A.J. Esbaugh, K. Frasier, S.B. Joye, G. Liu, K.L. Polzin, and A.C. Vaz. 2020. Transport, fate and impacts of the deep plume of petroleum hydrocarbons formed during the Macondo blowout. Frontiers in Marine Science 7:542147, https://doi.org/10.3389/ fmars.2020.542147.

Brandvik, P.J., Ø. Johansen, F. Leirvik, U. Farooq and P.S. Daling. 2013. Droplet breakup in subsurface oil releases: Part I. Experimental study of droplet breakup and effectiveness of dispersant injection. Marine Pollution Bulletin 73:319-326, https://doi.org/10.1016/j.marpolbul.2013.05.020.

Brandvik, P., Ø. Johansen, U. Farooq, G. Angell, and F. Leirvik. 2014. Subsurface Oil ReleasesExperimental Study of Droplet Distributions and Different Dispersant Injection Techniques, Version 2. SINTEF Report No. A26122, Trondheim, Norway, 134 pp.

Brandvik, P.J., C. Storey, E.J. Davies, and F. Leirvik. 2019. Quantification of oil droplets under high pressure laboratory experiments simulated deep water oil releases and subsea dispersants injection (SSDI). Marine Pollution Bulletin 138:520-525, https://doi.org/10.1016/j.marpolbul.2018.11.020.

Camilli, R., C.M. Reddy, D.R. Yoerger, B.A.S. Van Mooy, M.V. Jakuba, J.C. Kinsey, C.P. Mclntyre, S.P. Sylva, and J.V. Maloney. 2010. Tracking hydrocarbon plume transport and biodegradation at Deepwater Horizon. Science 330:201-204, https://doi.org/ 10.1126/science.1195223.

Cardona, Y., and A. Bracco. 2016. Predictability of mesoscale circulation throughout the water column in the Gulf of Mexico. Deep Sea Research Part // 129:332-349, https://doi.org/10.1016/ j.dsr2.2014.01.008.

Cardona, Y., D.V. Ruiz-Ramos, I.B. Baums, and A. Bracco. 2016. Potential connectivity of coldwater black coral communities in the northern Gulf of Mexico. PLOS ONE 11(5):e0156257, https://doi.org/ 10.1371/journal.pone.0156257.

Carrier, M., H. Ngodock, S. Smith, P. Muscarella, G. Jacobs, T. Özgökmen, B. Haus, and B. Lipphardt. 2014. Impact of assimilating ocean velocity observations inferred from Lagrangian drifter data using the NCOM-4DVAR. Monthly Weather Review 142:1,509-1,524, https://doi.org/10.1175/ MWR-D-13-00236.1

Chamecki, M., T. Chor, D. Yang, and C. Meneveau. 2019. Material transport in the ocean mixed layer: Recent developments enabled by large eddy simulations. Reviews of Geophysics 57(4):1,338-1,371, https://doi.org/10.1029/2019RG000655.

Chen, S.S., W. Zhao, M.A. Donelan, and H.L. Tolman. 2013. Directional wind-wave coupling in fully coupled atmosphere-wave-ocean models: Results from CBLAST-Hurricane. Journal of the Atmospheric Sciences 70(10):3,198-3,215, https://doi.org/10.1175/ JAS-D-12-0157.1.

Chen, S.S., and M. Curcic. 2016. Ocean surface waves in Hurricane Ike (2008) and Superstorm Sandy (2012): Coupled model predictions and observations. Ocean Modelling 103:161-176, https://doi.org/ 10.1016/j.ocemod.2015.08.005.

Chen, B., J. Huang, K. Yuan, L. Lin, X. Wang, L. Yang, and T. Luan. 2016a. Direct evidences on bacterial growth pattern regulating pyrene degradation pathway and genotypic dioxygenase expression. Marine Pollution Bulletin 105:73-80, https://doi.org/ 10.1016/j.marpolbul.2016.02.054.

Chen, B., D. Yang, C. Meneveau, and M. Chamecki. 2016b. ENDLESS: An extended nonperiodic domain large-eddy simulation approach for scalar plumes. Ocean Modelling 101:121-132, https://doi.org/10.1016/j.ocemod.2016.04.003.
Chen, B., D. Yang, C. Meneveau, and M. Chamecki. 2018. Numerical study of the effects of chemical dispersant on oil transport from an idealized underwater blowout. Physical Review Fluids 3(8):083801, https://doi.org/10.1103/PhysRevFluids.3.083801.

Choi, J., A. Bracco, R. Barkan, A.F. Shchepetkin, J.C. McWilliams, and J.M. Molemaker. 2017. Submesoscale dynamics in the northern Gulf of Mexico: Part III. Lagrangian implications. Journal of Physical Oceanography 47(9):2,361-2,376, https://doi.org/10.1175/JPO-D-17-0036.1.

Chu, S., and A. Prosperetti. 2016. Dissolution and growth of a multicomponent drop in an immiscible liquid. Journal of Fluid Mechanics 798:787-811, https://doi.org/10.1017/jfm.2016.310.

Crowe, M.N., and J.R. Taylor. 2018. The evolution of a front in turbulent thermal wind balance: Part 1. Theory. Journal of Fluid Mechanics 850:179-211, https://doi.org/10.1017/jfm.2018.448.

Cui, L. 2018. Tidal-, Wind-, and Buoyancy-Driven Dynamics in the Barataria Estuary and its Impact on Estuarine-Shelf Exchange Processes. PhD Dissertation, Louisiana State University, 165 pp.

Curcic, M., S.S. Chen, and T.M. Özgökmen. 2016. Hurricane-induced ocean waves and Stokes drift and their impacts on surface transport and dispersion in the Gulf of Mexico. Geophysical Research Letters 43(6):2,773-2,781, https://doi.org/ 10.1002/2015GL067619.

D’Asaro, E.A., A.Y. Shcherbina, J.M. Klymak, J. Molemaker, G. Novelli, C.M. Guigand, A.C. Haza, B.K. Haus, E.H. Ryan, G.A. Jacobs, and others. 2018. Ocean convergence and the dispersion of flotsam. Proceedings of the National Academy of Sciences of the United States of America 115(6):1,162-1,167, https://doi.org/10.1073/ pnas.1718453115.

D’Asaro, E.A., D.F. Carlson, M. Chamecki, R.R. Harcourt, B.K. Haus, B. Fox-Kemper, M.J. Molemaker, A.C. Poje, and D. Yang. 2020. Advances in observing and understanding smallscale open ocean circulation during the Gulf of Mexico Research Initiative era. Frontiers in Marine Science 7(349), https://doi.org/10.3389/ fmars.2020.00349.

Dagestad, K.-F., J. Röhrs, Ø. Breivik, and B. Ådlandsvik. 2018. OpenDrift v1.0: A generic framework for trajectory modelling. Geoscientific Model Development 11(4):1,405-1,420 https://doi.org/10.5194/gmd-11-1405-2018.

Daly, K.L., U. Passow, J. Chanton, and D. Hollander. 2016. Assessing the impacts of oil-associated marine snow formation and sedimentation during and after the Deepwater Horizon oil spill. Anthropocene 13:18-33, https://doi.org/10.1016/ j.ancene.2016.01.006

Daly, K.L., A.C. Vaz, and C.B. Paris. 2020. Physical processes influencing the sedimentation and lateral transport of MOSSFA in the NE Gulf of Mexico. Pp. 300-314 in Scenarios and Responses to Future Deep Oil Spills. S. Murawski, D. Hollander, C. Aimsworth, C.B. Paris, M. Schluter, and D. Wetzer, eds, Spring Science, https://doi.org/ 10.1007/978-3-030-12963-7_18.

Daneshgar Asl, S., D. Dukhovskoy, M. Bourassa, and I.R. MacDonald. 2017. Hindcast modeling of oil slick persistence from natural seeps. Remote Sensing of Environment 189:96-107, https://doi.org/10.1016/ j.rse.2016.11.003.

Davies, E.J., P.J. Brandvik, F. Leirvik, and R. Nepstad. 2017. The use of wide-band transmittance imaging to size and classify suspended particulate matter in seawater. Marine Pollution Bulletin 115:105-114, https://doi.org/10.1016/j.marpolbul.2016.11.063.

DeGouw, J.A., A.M. Middlebrook, C. Warneke, R. Ahmadov, E.L. Atlas, R. Bahreini, D.R. Blake, C.A. Brock, J. Brioude, D.W. Fahey, and others. 2011. Organic aerosol formation downwind from the Deepwater Horizon oil spill. Science 331:1,295-1,299, https://doi.org/10.1126/ science.1200320.
Deng, J., M. Molaei, N. Chisholm, and K.J. Stebe. 2020. Motile bacteria at oil-water interfaces: Pseudomonas Aeruginosa. Langmuir 36(25):6,888-6,902, https://doi.org/ 10.1021/acs.langmuir.9b03578.

Diercks, A., R. Highsmith, V. Asper, D. Joung, Z. Zhou, and L. Guo. 2010. Characterization of subsurface polycyclic aromatic hydrocarbons at the Deepwate Horizon site. Geophysical Research Letters 37(20), https://doi.org/10.1029/2010GL045046.

Dissanayake, A.L., J. Gros, and S.A. Socolofsky. 2018. Integral models for bubble, droplet, and multiphase plume dynamics in stratification and crossflow. Environmental Fluid Mechanics 18:1,167-1,202 https://doi.org/10.1007/s10652-018-9591-y.

Fabregat, A., A. Poje, T. Özgökmen, and W.K. Dewar. 2016a. Effects of rotation on turbulent buoyant plumes in stratified environments. Journal of Geophysical Research 121(8):5,397-5,417, https://doi.org/10.1002/2016JC011737.

Fabregat, A., A. Poje, T. Özgökmen, and W.K. Dewar. 2016b. Dynamics of multiphase plumes with hybrid buoyancy sources in stratified environments. Physics of Fluids 28:095109, https://doi.org/ 10.1063/1.4963313.

Faillettaz, R., C.B. Paris, A.C. Vaz, N. Perlin,

Z.M. Aman, M. Schlüter, and S.M. Murawski. 2021 The choice of droplet size probability distribution function for oil spill modeling is not trivial. Marine Pollution Bulletin 163:111920, https://doi.org/10.1016/ j.marpolbul.2020.111920

Farrington, J.W., E.B. Overton, and U. Passow. 2021. Biogeochemical processes affecting the fate of discharged Deepwater Horizon gas and oil: New insights and remaining gaps in our understanding. Oceanography 34(1):76-97, https://doi.org/10.5670/ oceanog.2021.118.

Fraga, B., T. Stoesser, C.C.K. Lai, and S.A. Socolofsky. 2016. A LES-based Eulerian-Lagrangian approach to predict the dynamics of bubble plumes. Ocean Modelling 97:27-36, https://doi.org/10.1016/ j.ocemod.2015.11.005.

French-McCay, D., D. Crowley, J.J. Rowe, M. Bock, H. Robinson, R. Wenning, A.H. Walker, J. Joeckel, T.J. Nedwed, and T.F. Parkerton. 2018. Comparative risk assessment of spill response options for a deepwater oil well blowout: Part 1. Oil spill modeling. Marine Pollution Bulletin 133:1,001-1,015, https://doi.org/10.1016/j.marpolbul.2018.05.042.

French-McCay, D., D. Crowley, and L. McStay. 2019. Sensitivity of modeled oil fate and exposure from a subsea blowout to oil droplet sizes, depth, dispersant use, and degradation rates. Marine Pollution Bulletin 146:779-793, https://doi.org/10.1016/ j.marpolbul.2019.07.038.

Garcia-Pineda, O., I. MacDonald, C. Hu, J. Svejkovsky, M. Hess, D. Dukhovskoy, and S.L. Morey. 2013a. Detection of floating oil anomalies from the Deepwater Horizon oil spill with synthetic aperture radar. Oceanography 26(2):124-137, https://doi.org 10.5670/oceanog.2013.38.

Garcia-Pineda, O., I.R. MacDonald, X. Li, C.R. Jackson, and W.G. Pichel. 2013b. Oil spill mapping and measurement in the Gulf of Mexico with Textural Classifier Neural Network Algorithm (TCNNA). IEEE Journal of Selected Topics in Applied Earth Observations and Remote Sensing 6(6):2,517-2,525, https://doi.org/10.1109/ JSTARS.2013.2244061.

Griffiths, S.K. 2012. Oil release from Macondo well MC252 following the Deepwater Horizon accident. Environmental Science \& Technology 46:5,616-5,622, https://doi.org/10.1021/ es204569t.

Gopalan, B., and J. Katz. 2010. Turbulent shearing of crude oil mixed with dispersants generates long microthreads and microdroplets. Physical Review Letters 104:054501, https://doi.org/10.1103/ PhysRevLett.104.054501.

Gros, J., C.M. Reddy, R.K. Nelson, S.A. Socolofsky, and J.S. Arey. 2016. Simulating gas-liquidwater partitioning and fluid properties of petroleum under pressure: Implications for deep- 
sea blowouts. Environmental Science and Technology 50(14):7,397-7,408, https://doi.org/ 10.1021/acs.est.5b04617.

Gros, J., S.A. Socolofsky, A.L. Dissanayake, I. Jun, L. Zhao, M.C. Boufadel, C.M. Reddy, and J.S. Arey. 2017. Petroleum dynamics in the sea and influence of subsea dispersant injection during Deepwater Horizon. Proceedings of the National Academy of Sciences of the United States of America 114(38):10,065-10,070, https://doi.org/ 10.1073/pnas.1612518114.

Gros, J., A.L. Dissanayake, M.M. Daniels, C.H. Barker, W. Lehr, and S.A. Socolofsky. 2018. Oil spill modeling in deep waters: Estimation of pseudocomponent properties for cubic equations of state from distillation data. Marine Pollution Bulletin 137:627-637, https://doi.org/10.1016/ j.marpolbul.2018.10.047.

Haza, A.C., E. D’Asaro, H. Chang, S. Chen, M. Curcic, C. Guigand, H.S. Huntley, G. Jacobs, G. Novelli, T.M. Özgökmen, and others. 2018. Drogue-loss detection for surface drifters during the Lagrangian Submesoscale Experiment (LASER). Journal of Atmospheric and Oceanic Technology 35:705-725, https://doi.org/10.1175/ JTECH-D-17-0143.1.

Haza, A.C., N. Paldor, T.M. Özgökmen, G. Jacobs, S.S. Chen, and M. Curcic. 2019. Wind-based estimations of ocean surface currents from massive clusters of drifters in the Gulf of Mexico. Journal of Geophysical Research 124(8):5,844-5,869, https://doi.org/10.1029/2018JC014813.

Hazen, T.C., E.A. Dubinsky, T.Z. DeSantis, G.L. Andersen, Y.M. Piceno, N. Singh, J.K. Jansson, A. Probst, S.E. Borglin, J.L. Fortney, and others. 2010. Deep-sea oil plume enriches indigenous oil-degrading bacteria. Science 330(6001):204-208, https://doi.org 10.1126/science.1195979.

Hole, L.R., K.-F. Dagestad, J. Röhrs, C. Wettre, V.H. Kourafalou, Y. Androulidakis, H. Kang, M. Le Hénaff, and O. Garcia-Pineda. 2019. The DeepWater Horizon oil slick: Simulations of river front effects and oil droplet size distribution. Journal of Marine Science and Engineering 7(10), https://doi.org/10.3390/jmse7100329.

Holmes, J.V., G. Graettinger, and I.R. MacDonald 2017. Remote sensing of oil slicks for Deepwater Horizon damage assessment. Pp. 889-923 in Oil Spill Science and Technology, 2nd ed M. Fingas, ed., Elsevier, https://doi.org/10.1016/ B978-0-12-809413-6.00017-5.

Huang, H., D. Justic, R.R. Lane, J.W. Day, and J.E. Cable. 2011. Hydrodynamic response of the Breton Sound estuary to pulsed Mississippi River inputs. Estuarine, Coastal and Shelf Science 95(1):216-231, https://doi.org/10.1016/ j.ecss.2011.08.034.

Huang, R.M., O.L. Bass, and S.L. Pimm. 2017. Sooty tern (Onychoprion fuscatus) survival, oil spills, shrimp fisheries, and hurricanes. PeerJ 5:e3287, https://doi.org/10.7717/peerj.3287.

Huntley, H.S., B.L. Lipphardt, G. Jacobs, and A.D. Kirwan. 2015. Clusters, deformation, and dilation: Diagnostics for material accumulation regions. Journal of Geophysical Research 120(10):6,622-6,636, https://doi.org/ 10.1002/2015JC011036.

Jacobs, G.A., B.P. Bartels, D.J. Bogucki, F.J. BeronVera, S.S. Chen, E.F. Coelho, M. Curcic, A. Griffa, M. Gough, B.K. Haus, and others. 2014. Data assimilation considerations for improved ocean predictability during the Gulf of Mexico Grand Lagrangian Deployment (GLAD). Ocean Modelling 83:98-117, https://doi.org/10.1016/j.ocemod.2014.09.003.

Jaggi, A., R.W. Snowdon, A. Stopford, J.R. Radovic, T.B.P. Oldenburg, and S.R. Larter. 2017. Experimental simulation of crude oil-water partitioning behavior of BTEX compounds during a deep submarine oil spill. Organic Geochemistry 108:1-8, https://doi.org/10.1016/j.orggeochem.2017.03.006.
Jaggi, A., R.W. Snowdon, J.R. Radović, A. Stopford, T.B.P. Oldenburg, and S.R. Larter. 2020. Partitioning of organics between oil and water phases with and without the application of dispersants. Pp. 125-138 in Deep Oil Spills: Facts, Fate, Effects. S.A. Murawski, C.H. Ainsworth, S. Gilbert, D.J. Hollander, C.B. Paris, M. Schlüter, and D.L. Wetzel, eds, Springer International, https://doi.org/10.1007/978-3-030-11605-7_8.

Jalali, M., A.R. White, J. Marti, and J. Sheng. 2018. Fabrication and characterization of a scalable surface textured with pico-liter oil drops for mechanistic studies of bacterial-oil interactions. Scientific Reports 8:7612, https://doi.org/10.1038/ s41598-018-25812-y.

Johansen, $\emptyset$. 2003. Development and verification of deep-water blowout models. Marine Pollution Bulletin 47(9-12):360-368, https://doi.org/10.1016/ S0025-326x(03)00202-9.

Johansen, Ø., P.J. Brandvik, and U. Farooq. 2013. Droplet breakup in subsea oil releases: Part 2. Predictions of droplet size distributions with and without injection of chemical dispersants. Marine Pollution Bulletin 73:327-335, https://doi.org/ 10.1016/j.marpolbul.2013.04.012.

Johansen, $\varnothing .$, M. Reed, and N.R. Bodsberg. 2015. Natural dispersion revisited. Marine Pollution Bulletin 93:20-26, https://doi.org/10.1016/ j.marpolbul.2015.02.026.

Joye, S.B., A. Bracco, T.M. Özgökmen, J.P. Chanton, M. Grosell, I.R. MacDonald, E.E. Cordes, J.P. Montoya, and U. Passow. 2016a. The Gulf of Mexico ecosystem, six years after the Macondo oi well blowout. Deep Sea Research Part II 129:4-19, https://doi.org/10.1016/j.dsr2.2016.04.018.

Joye, S.B., S. Kleindienst, J.A. Gilbert, K.M. Handley, P. Weisenhorn, W.A. Overholt, and J.E. Kostka. 2016b. Responses of microbial communities to hydrocarbon exposures Oceanography 29(3):136-149, https://doi.org/ 10.5670/oceanog.2016.78.

Judt, F., S.S. Chen, and M. Curcic. 2016. Atmospheric forcing of ocean transport in the Gulf of Mexico from seasonal to diurnal scales. Journal of Geophysical Research 121:4,416-4,433, https://doi.org/10.1002/2015JC011555.

Justić, D., and L. Wang. 2014. Assessing temporal and spatial variability of hypoxia over the inner Louisiana-upper Texas shelf: Application of an unstructured-grid three-dimensional coupled hydrodynamic-water quality model. Continental Shelf Research 72:163-179, https://doi.org/10.1016/ j.csr.2013.08.006

Katz, J., and J. Sheng. 2010. Applications of holography in fluid mechanics and particle dynamics. Annual Review of Fluid Mechanics 42:531-555, https://doi.org/10.1146/annurev-fluid-121108-145508.

Kessler, J.D., D.L. Valentine, M.C. Redmond, M. Du, E.W. Chan, S.D. Mendes, E.W. Quiroz, C.J. Villanueva, S.S. Shusta, L.M. Werra, and others 2011. A persistent oxygen anomaly reveals the fate of spilled methane in the deep Gulf of Mexico. Science 331:312-315, https://doi.org/10.1126 science.1199697.

Khelifa, A., M. Fingas, and C. Brown. 2008. Effects of Dispersants on Oil-SPM Aggregation and Fate in US Coastal Waters. NOAA/UNH Coastal Response Research Center, Durham, NH, 57 pp.

Kourafalou, V.H., and Y.S. Androulidakis. 2013. Influence of Mississippi induced circulation on the Deepwater Horizon Oil Spill transport. Journal of Geophysical Research 118:1-20, https://doi.org/ 10.1002/jgrc.20272.

Lai, C.C.K., and S.A. Socolofsky. 2019. The turbulent kinetic energy budget in a bubble plume. Journal of Fluid Mechanics 865:993-1,041, https://doi.org/ $10.1017 / \mathrm{jfm} .2019 .66$

Ledwell, J.R., R. He, Z. Xue, S.F. DiMarco, L. Spencer, and P. Chapman. 2016. Dispersion of a trace in the deep northern Gulf of Mexico. Journal of Geophysical Research 121(2):1,110-1,132, https://doi.org/10.1002/2015JC011405.
Le Hénaff, M., V.H. Kourafalou, C.B. Paris, J. Helgers, P.J. Hogan, and A. Srinivasan. 2012. Surface evolution of the Deepwater Horizon oil spill: Combined effects of circulation and wind induced drift. Environmental Science \& Technology 46:7,267-7,273, https://doi.org/ 10.1021/es301570w.

Lehr, W., S. Bristol, and A. Possolo. 2010. Oil Budget Calculator, Deepwater Horizon. Technical Documentation, The Federal Interagency Solutions Group, 217 pp., http://www.restorethegulf.gov/sites/ default/files/documents/pdf/OilBudgetCalc_Full_ HQ-Print 111110.pdf.

Leifer, I., W.J. Lehr, D. Simecek-Beatty, E. Bradley, R. Clark, P. Dennison, Y.X. Hu, S. Matheson, C.E. Jones, B. Holt, and others. 2012. State of the art satellite and airborne marine oil spill remote sensing: Application to the BP Deepwater Horizon oil spill. Remote Sensing of Environment 124:185-209, https://doi.org/10.1016/ j.rse.2012.03.024.

Li, C., J. Miller, J. Wang, S. Koley, and J. Katz. 2017. Size distribution and dispersion of droplets generated by impingement of breaking waves on oil slicks. Journal of Geophysical Research 122(10):7,938-7,957, https://doi.org/ 10.1002/2017JC013193.

Li, M., Z. Zhao, Y. Pandya, G.V. lungo, and D. Yang. 2019. Large-Eddy Simulations of oil droplet aerosol transport in the marine atmospheric boundary layer. Atmosphere 10(8):459, https://doi.org/ 10.3390/atmos10080459.

Li, Z., K. Lee, T. King, M.C. Boufadel, and A.D. Venosa. 2008a. Assessment of chemical dispersant effectiveness in a wave tank under regular non-breaking and breaking wave conditions. Marine Pollution Bulletin 56(5):903-912, https://doi.org/10.1016/ j.marpolbul.2008.01.031.

Li, Z., K. Lee, T. King, M.C. Boufadel, and A.D. Venosa. 2008b. Oil droplet size distribution as a function of energy dissipation rate in an experimental wave tank. International Oil Spill Conference Proceedings 2008(1):621-626, https://doi.org/ 10.7901/2169-3358-2008-1-621.

Li, Z., M.L. Spaulding, and D. French-McCay. 2017a. An algorithm for modeling entrainment and naturally and chemically dispersed oil droplet size distribution under surface breaking wave conditions. Marine Pollution Bulletin 119:45-152, https://doi.org/ 10.1016/j.marpolbul.2017.03.048.

Li, Z., M. Spaulding, D.F. McCay, D. Crowley, and J.R. Payne. 2017b. Development of a unified oil droplet size distribution model with application to surface breaking waves and subsea blowout releases considering dispersant effects. Marine Pollution Bulletin 114(1):247-257, https://doi.org/ 10.1016/j.marpolbul.2016.09.008.

Lindo-Atichati, D., C.B. Paris, M. Le Hénaff, M. Schedler, A.G. Valladares Juárez, and A. Müller. 2014. Simulating the effects of droplet size, high-pressure biodegradation, and variable flow rate on the subsea evolution of deep plumes from the Macondo blowout. Deep Sea Research Part // 129:301-310, https://doi.org/10.1016/ j.dsr2.2014.01.011.

Lindo-Atichati, D., C.B. Paris, M. Le Hénaff, M. Schedler, A.G. Valladares Juárez, and R. Müller. 2016. Simulating the effects of droplet size, high-pressure biodegradation, and variable flow rate on the subsea evolution of deep plumes from the Macondo blowout. Deep Sea Research Part // 129:301-310, https://doi.org/10.1016/ j.dsr2.2014.01.011.

Luo, H., A. Bracco, Y. Cardona, and J.C. McWilliams. 2016. Submesoscale circulation in the northern Gulf of Mexico: Surface processes and the impact of the freshwater river input. Ocean Modelling 101:68-82, https://doi.org/10.1016/j.ocemod.2016.03.003.

MacDonald, I.R., O. Garcia-Pineda, A. Beet, S. Daneshgar Asl, L. Feng, G. Graettinger D. French-McCay, J. Holmes, C. Hu, F. Huffer, and others. 2015. Natural and unnatural oil slicks 
in the Gulf of Mexico. Journal of Geophysical Research 120:8,364-8,380, https://doi.org/ 10.1002/2015JC011062

MacDonald, I. 2019. "Neural Network Analysis Determination of Oil Slick Distribution and Thickness from Satellite Synthetic Aperture Radar, April 24-August 3, 2010." Gulf of Mexico Research Initiative Information and Data Cooperative (GRIIDC), Harte Research Institute, Texas A\&M University, Corpus Christi, https://doi.org/10.7266/ N7KW5CZN.

Malone, K., S. Pesch, M. Schlüter, and D. Krause. 2018. Oil droplet size distributions in deepsea blowouts: Influence of pressure and dissolved gases. Environmental Science \& Technology 52(11):6,326-6,333, https://doi.org/ 10.1021/acs.est.8b00587.

Malone, K., Z.M. Aman, S. Pesch, M. Schlüter, and D. Krause. 2020. Jet formation at the spill site and resulting droplet size distributions. Pp. 43-64 in Deep Oil Spills: Facts, Fate, Effects. S.A. Murawski, C.H. Ainsworth, S. Gilbert, D.J. Hollander, C.B. Paris, M. Schlüter, and D.L. Wetzel, eds, Springer International, https://doi.org/10.1007/ 978-3-030-11605-7_4.

Martin, C.W., K.A. Lewis, A.M. McDonald, T.P. Spearman, S.B. Alford, R.C. Christian, and J.F. Valentine. 2020. Disturbance-driven changes to northern Gulf of Mexico nekton communities following the Deepwater Horizon oil spill. Marine Pollution Bulletin 155:111098, https://doi.org/ 10.1016/j.marpolbul.2020.111098.

Mensa, J., M.-L. Timmermans, I. Kozlov, S. Zimmerman, W. Williams, and T.M. Özgökmen. 2018. Surface drifter observations from the Arctic Ocean's Beaufort Sea: Evidence of submesoscale dynamics. Journal of Geophysical Research 123(4):2,635-2,645, https://doi.org/ 10.1002/2017JC013728.

Molaei, M., and J. Sheng. 2014. Imaging bacterial 3D motion using digital in-line holographic microscopy and correlation-based de-noising algorithm. Optics Express 22(26):32,119-32,137, https://doi.org/ 10.1364/OE.22.032119.

Morey, S., N. Wienders, D. Dukhovskoy, and M. Bourassa. 2018. Measurement characteristics of near-surface currents from ultra-thin drifters, drogued drifters, and HF radar. Remote Sensing 10(10):1633, https://doi.org/10.3390/ rs10101633.

Murawski, S., M. Schlüter, C.B. Paris, and Z.M. Aman 2019. Resolving the dilemma of dispersant use for deep oil spill response. Environment Research Letters 14:091002, https://doi.org/10.1088/ 1748-9326/ab3aaO.

Murphy, D.W., C. Li, V. d'Albignac, D. Morra, and J. Katz. 2015. Splash behaviour and oily marine aerosol production by raindrops impacting oil slicks. Journal of Fluid Mechanics 780:536-577, https://doi.org/10.1017/jfm.2015.431.

Murphy, D.W., X. Xue, K. Sampath, and J. Katz. 2016. Crude oil jets in crossflow: Effects of dispersant concentration on plume behavior. Journal of Geophysical Research 121(6):4,264-4,281, https://doi.org/10.1002/2015JC011574.

Muscarella, P.A., M. Carrier, H. Ngodock, S. Smith, B. Lipphardt, A.D. Kirwan, and H. Huntley. 2015. Do assimilated drifter velocities improve Lagrangian predictability in an operational ocean model? Monthly Weather Review 143:1,822-1,832, https://doi.org/10.1175/MWR-D-14-001641.

Niepa, T.H., L. Vaccari, R.L. Leheny, M. Goulian, D. Lee, and K.J. Stebe. 2017. Films of bacteria at interfaces (FBI): Remodeling of fluid interfaces by Pseudomonas aeruginosa. Scientific Reports 7:17864, https://doi.org/10.1038/ s41598-017-17721-3.

North, E.W., Z. Schlag, E.E. Adams, C.R. Sherwood, R. He, K.H. Hyun, and S.A. Socolofsky. 2011. Simulating oil droplet dispersal from the Deepwater Horizon spill with a Lagrangian approach. Pp. 217-226 in Monitoring and Modeling the
Deepwater Horizon Oil Spill: A Record-Breaking Enterprise. Y. Liu, A. Macfadyen, Z.-G. Ji, R.H. Weisberg, eds, American Geophysical Union Monograph Series, vol. 195.

North, E.W., E.E. Adams, A.E. Thessen, Z. Schlag, R. He, S.A. Socolofsky, S.M. Masutani, and S.D. Peckham. 2015. The influence of droplet size and biodegradation on the transport of subsurface oil droplets during the Deepwater Horizon spill: A model sensitivity study. Environmental Research Letters 10(2):024016, https://doi.org/10.1088/ 1748-9326/10/2/024016.

Novelli, G., C. Guigand, C. Cousin, E. Ryan, N. Laxague, H. Dai, B. Haus, and T.M. Özgökmen. 2017. A biodegradable surface drifter for ocean sampling on a massive scale. Journal of Atmospheric and Oceanic Technology 34(11):2,509-2,532, https://doi.org/ 10.1175/JTECH-D-17-0055.1.

Novelli, G., C.M. Guigand, M.C. Boufadel, and T.M. Özgökmen. 2020. On the transport and landfall of marine oil spills, laboratory and field observations. Marine Pollution Bulletin 150:110805, https://doi.org/10.1016/j.marpolbul.2019.110805.

Özgökmen, T.M., M. Boufadel, D. Carlson, C. Cousin, C. Guigand, B. Haus, J. Horstmann, B. Lund, J. Molemaker, and G. Novelli. 2018. Technological advances for ocean surface measurements by the Consortium of Advanced Research for Hydrocarbons in the Environment (CARTHE). Marine Technology Society Journal 52:71-76, https://doi.org/10.4031/MTSJ.52.6.11.

Paris, C.B., M. Le Hénaff, Z.M. Aman, A. Subramaniam, J. Helgers, D.P. Wang, V.H. Kourafalou, and A. Srinivasan. 2012. Evolution of the Macondo well blowout: Simulating the effects of the circulation and synthetic dispersants on the subsea oil transport. Environmental Science \& Technology 46:13,293-13,302, https://doi.org/ 10.1021/es303197h.

Paris, C.B., J. Helgers, E. van Sebille, and A. Srinivasan. 2013. Connectivity modeling system: A probabilistic modeling tool for the multiscale tracking of biotic and abiotic variability in the ocean. Environmental Modelling \& Software 42:47-54, https://doi.org/10.1016 j.envsoft.2012.12.006.

Paris, C.B., I. Berenshtein, M.L. Trillo, R. Faillettaz, M.J. Olascoaga, Z.M. Aman, M. Schlüter, and S.B. Joye. 2018. BP gulf science data reveals ineffectual sub-sea dispersant injection for the Macondo blowout. Frontiers in Marine Science 5:389, https://doi.org/10.3389/ fmars.2018.00389.

Paris, C.B., S.A. Murawski, M.J. Olascoaga, A.C. Vaz, I. Berenshtein, P. Miron, and F.J. Beron-Vera. 2020. Connectivity of the Gulf of Mexico continental shelf fish populations and implications of simulated oil spills. Pp. 369-389 in Scenarios and Responses to Future Deep Oil Spills: Fighting the Next War. S.A. Murawski, C.H. Ainsworth, S. Gilbert, D.J. Hollander, C.B. Paris, M. Schlüter, and D.L. Wetzel, eds, Springer Nature, https://doi.org/ 10.1007/978-3-030-12963-7_22.

Perlin, N., C.B. Paris, I. Berenshtein, A.C. Vaz, R. Faillettaz, Z.M. Aman, P.T. Schwing, I.C. Romero, M. Schlüter, A. Liese, and others. 2020. Far-field modeling of deep-sea blowout: Sensitivity studies of initial conditions, biodegradation, sedimentation and SSDI on surface slicks and oil plume concentrations. Pp. 170-192 in Deep Oil Spills: Facts, Fate, Effects. S.A. Murawski, C. Ainsworth, S. Gilbert, D. Hollander, C.B. Paris, M. Schlüter, and D.L. Wetzel, Springer International, https://doi.org/ 10.1007/978-3-030-11605-7_11.

Pesch, S., P. Jaeger, A. Jaggi, K. Malone, M. Hoffmann, D. Krause, T.B.P. Oldenburg, and M. Schlüter 2018. Rise velocity of live-oil droplets in deepsea oil spills. Environmental Engineering Science 35(4):289-299, https://doi.org/10.1089/ ees.2017.0319.
Pesch, S., R. Knopf, A. Radmehr, C.B. Paris,

Z.M. Aman, M. Hoffmann, and M. Schlüter. 2020a.

Experimental investigation, scale-up and modeling of droplet size distributions in turbulent multiphase jets. Multiphase Science and Technology 32(2):113-136, https://doi.org/10.1615/ MultScienTechn.2020031347.

Pesch, S., M. Schlüter, Z.M. Aman, K. Malone, D. Krause, and C.B. Paris. 2020b. Behavior of rising droplets and bubbles: Impact on the physics of deep-sea blowouts and oil fate. Pp. 65-82 in Deep Oil Spills: Facts, Fate and Effects. S.A. Murawski, C. Ainsworth, S. Gilbert, D. Hollander, C.B. Paris, M. Schlüter, and D. Wetzel, eds, Springer International, https://doi.org/10.1007/ 978-3-030-11605-7 5.

Polzin, K.L., N. Garabato, A.C. Huussen, B. Sloyan, and S. Waterman. 2014. Finescale parameterizations of turbulent dissipation. Journal of Geophysical Research 119:1,383-1,419, https://doi.org/10.1002/ 2013JC008979.

Price, E.R., and E.M. Mager. 2020. The effects of exposure to crude oil or PAHs on fish swim bladder development and function. Comparative Biochemistry and Physiology C-Toxicology \& Pharmacology 238:108853, https://doi.org/10.1016/ j.cbpc. 2020.108853.

Quigg, A., J.W. Farrington, S. Gilbert, S.A. Murawski, and V.T. John. 2021. A decade of GoMRI dispersant science: Lessons learned and recommendations for the future. Oceanography 34(1):98-111 https://doi.org/10.5670/oceanog.2021.119.

Rodríguez, E., A. Wineteer, D. Perkovic-Martin, T. Gál, B. Stiles, N. Niamsuwan, and R.R. Monje. 2018. Estimating ocean vector winds and currents using a Ka-Band Pencil-Beam Doppler Scatterometer. Remote Sensing 10(4):576, https://doi.org/10.3390/ rs10040576.

Rogener, M.K., A. Bracco, K.S. Hunter, M.A. Saxton, and S.B. Joye. 2018. Long-term impact of the Deepwater Horizon oil well blowout on meth ane oxidation dynamics in the northern Gulf of Mexico. Elementa 6:73, https://doi.org/10.1525/ elementa.332.

Romero, I.C., H. Judkins, and M. Vecchione. 2020 Temporal variability of polycyclic aromatic hydrocarbons in deep-sea cephalopods of the northern Gulf of Mexico. Frontiers in Marine Science 7:264, https://doi.org/10.3389/fmars.2020.00264.

Sampath, K., N. Afshar-Mohajer, L.D. Chandrala, W.S. Heo, J. Gilbert, D. Austin, K. Koehler, and J. Katz. 2019. Aerosolization of crude oildispersant slicks due to bubble bursting. Journal of Geophysical Research 124(10):5,555-5,578, https://doi.org/10.1029/2018JD029338.

Sheng, J., E. Malkiel, and J. Katz. 2006. Digital holographic microscope for measuring three-dimensional particle distributions and motions. Applied Optics 45(16):3,893-3,901, https://doi.org/10.1364 A0.45.003893.

Socolofsky, S.A., E.E. Adams, and C.R. Sherwood. 2011. Formation dynamics of subsurface hydrocarbon intrusions following the Deepwater Horizon blowout. Geophysical Research Letters 38(9), https://doi.org/10.1029/2011GL047174.

Socolofsky, S.A., E.E. Adams, M.C. Boufadel, Z.M. Aman, Ø. Johansen, W.J. Konkel, D. Lindo, M.N. Madsen, E.W. North, C.B. Paris, and others. 2015. Intercomparison of oil spill prediction models for accidental blowout scenarios with and without subsea chemical dispersant injection. Marine Pollution Bulletin 96(1-2):110-126, https://doi.org/ 10.1016/j.marpolbul.2015.05.039.

Socolofsky, S.A., E.E. Adams, C.B. Paris, and D. Wang. 2016. How do oil, gas, and water interact near a subsea blowout? Oceanography 29(3):64-75, https://doi.org/10.5670/oceanog.2016.63.

Sullivan, P., and J. McWilliams. 2018. Frontogenesis and frontal arrest of a dense filament in the oceanic surface boundary layer. Journal of Fluid Mechanics 837:341-380, https://doi.org/10.1017/ jfm.2017.833. 
Tseng, Y.-H., and A. Prosperetti. 2015. Local interfacial stability near a zero vorticity point. Journal of Fluid Mechanics 776:5-36, https://doi.org/10.1017/ jfm.2015.246

Vaccari, L., D.B. Allan, N. Sharifi-Mood, A.R. Singh, R.L. Leheny, and K.J. Stebe. 2015. Films of bacteria at interfaces: Three stages of behaviour. Soft Matter 11(30):6,062-6,074, https://doi.org/10.1039/ C5SM00696A.

Vaccari, L., M. Molaei, T.H. Niepa, D. Lee, R.L. Leheny, and K.J. Stebe. 2017. Films of bacteria at interfaces. Advances in Colloid and Interface Science 247:561-572, https://doi.org/10.1016/ j.cis. 2017.07.016.

Vaccari, L., M. Molaei, R.L. Leheny, and K.J. Stebe. 2018. Cargo carrying bacteria at interfaces. Soft Matter 14(27):5,643-5,653, https://doi.org/10.1039/ C8SM00481A.

Valentine, K., and G. Mariotti, 2019. Wind-driven water level fluctuations drive marsh edge erosion variability in microtidal coastal bays. Continental Shelf Research 176:76-89, https://doi.org/10.1016/ j.csr.2019.03.002.

Vaz, A.C., C.B. Paris, A.L. Dissanayake,

S.A. Socolofsky, J. Gros, and M.C. Boufadel. 2020 Dynamic coupling of near-field and far-field models. Pp. 139-154 in Deep Oil Spills: Facts, Fate, and Effects. Springer International, https://doi.org/ 10.1007/978-3-030-11605-7 9.

Vaz, A.C., C.B. Paris, A.L. Dissanayake, S.A. Socolofsky, J. Gros, and M.C. Boufadel. 2019 Direct coupling of near-field and far-field models hones predictions of oil spill transport and fate from deep-sea blowout. Pp. 502-521 in Proceedings of $42^{\text {nd }}$ Arctic and Marine Oilspill Program Technical Seminar on Environmental Contamination and Response, June 14-19, 2019, Halifax, Canada.

Veron, F. 2015. Ocean spray. Annual Review of Fluid Mechanics 47:507-538, https://doi.org/10.1146/ annurev-fluid-010814-014651.

Wang, B., S.A. Socolofsky, J.A. Breier, and J.S. Seewald. 2016. Observations of bubbles in natural seep flares at MC 118 and GC 600 using in situ quantitative imaging. Journal of Geophysical Research 121(4):2,203-2,230, https://doi.org/ 10.1002/2015JC011452.

Wang, B., C.C.K. Lai, and S.A. Socolofsky. 2019. Mean velocity, spreading and entrainment characteristics of weak bubble plumes in unstratified and stationary water. Journal of Fluid Mechanics 874:102-130, https://doi.org/10.1017/jfm.2019.461.

Wang, B., I. Jun, S.A. Socolofsky, S.F. DiMarco, and J.D. Kessler. 2020. Dynamics of gas bubbles from a submarine hydrocarbon seep within the hydrate stability zone. Geophysical Research Letters 47(18):e2020GL089256, https://doi.org/ 10.1029/2020GL089256.

Wang, D., and E.E. Adams. 2016. Intrusion dynamics of particle plumes in stratified water with weak crossflow: Application to deep ocean blowouts. Journal of Geophysical Research 121(6):3,820-3,835, https://doi.org/10.1002/2015JC011324.

Wei, Z.P., C. Li, R.A. Dalrymple, M. Derakhti, and J. Katz. 2018. Chaos in breaking waves. Coastal Engineering 140:272-291, https://doi.org/10.1016/ coastaleng.2018.08.001.

Weisberg, R.H., L. Zheng, and E. Peebles. 2014. Gag grouper larvae pathways on the West Florida Shelf. Continental Shelf Research 88:11-23, https://doi.org/10.1016/j.csr.2014.06.003.

Wenegrat, J.O., M.J. McPhaden, and R.-C. Lien. 2014. Wind stress and near-surface shear in the equatorial Atlantic Ocean. Geophysical Research Letters 41(4):1,226-1,231, https://doi.org/ 10.1002/2013GL059149.

Westerholm, D.G., C.H. Ainsworth, C.H. Barker, P.G. Brewer, J.W. Farrington, D. Justić, V.H. Kourafalou, S.A. Murawski, J.G. Shepherd, and H.M. Solo-Gabriele. 2021. Preparedness, planning, and advances in operational response. Oceanography 34(1):212-227, https://doi.org/ 10.5670/oceanog.2021.127.
White, A., M. Jalali, C. Boufadel, and J. Sheng. 2019a. Bacteria forming drag-increasing streamers on a drop implicates complementary fates of rising deep-sea oil droplets. Scientific Report 10:4305, https://doi.org/10.1038/s41598-020-61214-9.

White, A.R., M. Jalali, and J. Sheng. 2019b. A new ecology-on-a-chip microfluidic platform to study interactions of microbes with a rising oil droplet. Scientific Reports 9:13737, https://doi.org/10.1038/ s41598-019-50153-9.

White, E., F. Messina, L. Moss, and E. Meselhe. 2018. Salinity and marine mammal dynamics in Barataria Basin: Historic patterns and modeled diversion scenarios. Water 10(8):1015, https://doi.org/10.3390/ w10081015.

White, J.A., H. Nishikawa, and R.A. Baurle. 2019c Weighted least-squares cell-average gradient construction methods for the VULCAN-CFD secondorder accurate unstructured grid cell-centered finite-volume solver. AIAA Scitech 2019 Forum January 7-11, 2019, San Diego, CA, https://doi.org/ 10.2514/6.2019-0127.

Xue, X.Z., and J. Katz. 2019. Formation of compound droplets during fragmentation of turbulent buoyant oil jet in water. Journal of Fluid Mechanics 878:98-112, https://doi.org/10.1017/ jfm.2019.645.

Yang, D., B. Chen, S.A. Socolofsky, M. Chamecki, and C. Meneveau. 2016. Large-eddy simulation and parameterization of buoyant plume dynamics in stratified flow. Journal of Fluid Mechanics 794:798-833, https://doi.org/10.1017/ jfm.2016.191.

Zengel, S., B.M. Bernik, N. Rutherford, Z. Nixon, and J. Michel. 2015. Heavily oiled salt marsh following the Deepwater Horizon oil spill, ecological compar isons of shoreline cleanup treatments and recovery. PLoS ONE 10(7):e0132324, https://doi.org/ 10.1371/journal.pone.0132324.

Zhao, L., M.C. Boufadel, S.A. Socolofsky, E. Adams, T. King, and K. Lee. 2014a. Evolution of droplets in subsea oil and gas blowouts: Development and validation of the numerical model VDROP-J. Marine Pollution Bulletin 83:58-69, https://doi.org/10.1016/ j.marpolbul.2014.04.020.

Zhao, L., J. Torlapati, M.C. Boufadel, T. King, B. Robinson, and K. Lee. 2014b. VDROP: A comprehensive model for droplet formation of oils and gases in liquids-Incorporation of the interfacial tension and droplet viscosity. Chemical Engineering Journal 253:93-106, https://doi.org/ 10.1016/j.cej.2014.04.082.

Zhao, L., M.C. Boufadel, E.E. Adams, S. Socolofsky, T. King, and K. Lee. 2015. Simulation of scenarios of oil droplet formation from the Deepwater Horizon blowout. Marine Pollution Bulletin 101(1):304-319, https://doi.org/10.1016/j.marpolbul.2015.10.068.

Zhao, L., F. Shaffer, B. Robinson, T. King, C. D’Ambrose, Z. Pan, F. Gao, R.S. Miller, R.N. Conmy, and M.C. Boufadel. 2016. Underwater oil jet: Hydrodynamics and droplet size distribution. Chemical Engineering Journal 299:292-303, https://doi.org/10.1016/j.cej.2016.04.061.

Zhao, L., F. Gao, M.C. Boufadel, T. King, B. Robinson, K. Lee, and R. Conmy. 2017. Oil jet with dispersant: Macro-scale hydrodynamics and tip streaming. AlChE Journal 63(11):5,222-5,234, https://doi.org/ 10.1002/aic.15864.

Zheng, L., P.D. Yapa, and F.H. Chen. 2003. A model for simulating deepwater oil and gas blowouts: Part I. Theory and model formulation. Journal of Hydraulic Research 41(4):339-351, https://doi.org/ 10.1080/00221680309499980.

Zheng, L., and R.H. Weisberg. 2010. Rookery Bay and Naples Bay circulation simulations: Applications to tides and fresh water inflow regulation. Ecological Modelling 221(7):986-996, https://doi.org/10.1016/ j.ecolmodel.2009.01.024.

Zheng, L., and R.H. Weisberg. 2012. Modeling the west Florida coastal ocean by downscaling from the deep ocean, across the continental shelf and into the estuaries. Ocean Modelling 48:10-29, https://doi.org/10.1016/j.ocemod.2012.02.002.

\section{AUTHORS}

Michel Boufadel is Professor, Civil \& Environmental Engineering, New Jersey Institute of Technology, Newark, NJ, USA. Annalisa Bracco is Professor, School of Earth and Atmospheric Sciences, Georgia Institute of Technology, Atlanta, GA, USA. Eric P. Chassignet is Director, Center for Ocean-Atmospheric Prediction Studies, and Professor, Department of Earth, Ocean, and Atmospheric Sciences, Florida State University, Tallahassee, FL, USA. Shuyi S. Chen is Professor, Department of Atmospheric Sciences, University of Washington, Seattle, WA, USA. Eric D'Asaro is Senior Principal Oceanographer, Applied Physics Laboratory, University of Washington, Seattle, WA USA. William K. Dewar is Professor, Department of Earth, Ocean, and Atmospheric Sciences, Florida State University, Tallahassee, FL, USA Oscar Garcia-Pineda is Director, Water Mapping LLC, Gulf Breeze, FL, USA. Dubravko Justić is Professor, Department of Oceanography and Coastal Sciences, College of the Coast \& Environment, Louisiana State University, Baton Rouge, LA, USA. Joseph Katz is Professor, Center for Environmental and Applied Fluid Mechanics, Johns Hopkins University, Baltimore, MD, USA. Vassiliki H. Kourafalou is Research Professor, Rosenstiel School of Marine and Atmospheric Science, University of Miami, Miami, FL, USA. Ian R. MacDonald is Professor, Department of Earth, Ocean, and Atmospheric Sciences, Florida State University, Tallahassee, FL, USA. Tamay M. Özgökmen is Professor and Claire B. Paris-Limouzy is Professor, both in the Department of Ocean Sciences, Rosenstiel School of Marine and Atmospheric Science, University of Miami, Miami, FL, USA. Scott S. Socolofsky is Professor, Zachry Department of Civil \& Environmental Engineering, Texas A\&M University, College Station, TX, USA. David Halpern is GoMRI Research Board member and Affiliate Researcher, Scripps Institution of Oceanography, University of California San Diego, La Jolla, CA, USA. John G. Shepherd (jgs@noc. soton.ac.uk) is GoMRI Research Board member and Professorial Research Fellow, School of Ocean \& Earth Science, National Oceanography Centre, University of Southampton, Southampton, UK.

\section{ARTICLE CITATION}

Boufadel, M., A. Bracco, E.P. Chassignet, S.S. Chen, E. D’Asaro, W.K. Dewar, O. Garcia-Pineda, D. Justić, J. Katz, V.H. Kourafalou, I.R. MacDonald, T.M. Özgökmen, C.B. Paris-Limouzy, S.S. Socolofsky, D. Halpern, and J.G. Shepherd. 2021. Physical transport processes that affect the distribution of oil in the Gulf of Mexico: Observations and modeling. Oceanography 34(1):58-75, https://doi.org/10.5670/ oceanog.2021.117.

\section{COPYRIGHT \& USAGE}

This is an open access article made available under the terms of the Creative Commons Attribution 4.0 International License (https://creativecommons.org/ licenses/by/4.0/), which permits use, sharing, adaptation, distribution, and reproduction in any medium or format as long as users cite the materials appropriately, provide a link to the Creative Commons license, and indicate the changes that were made to the original content. 